Progress in Oceanography

August 2016, Volume 146, Pages 142-158

http://dx.doi.org/10.1016/j.pocean.2016.06.007

http://archimer.ifremer.fr/doc/00345/45569/

(C) 2016 Elsevier Ltd. All rights reserved.

\title{
The northern North Atlantic Ocean mean circulation in the early 21st Century
}

\author{
Daniault Nathalie ${ }^{1,{ }^{*}}$, Mercier Herle ${ }^{2}$, Lherminier Pascale ${ }^{3}$, Sarafanov Artem ${ }^{4}$, Falina Anastasia ${ }^{4}$, \\ Zunino Patricia ${ }^{3}$, Pérez Fiz F ${ }^{6}$, Ríos Aida F., Ferron Bruno ${ }^{2}$, Huck Thierry ${ }^{5}$, Thierry Virginie ${ }^{3}$, \\ Gladyshev Sergey ${ }^{4}$
}

\footnotetext{
${ }^{1}$ Univ. Brest, CNRS, IRD, Ifremer, Laboratoire d'Océanographie Physique et Spatiale (LOPS), IUEM, Brest, France

${ }^{2}$ CNRS, Ifremer, Univ. Brest, IRD, Laboratoire d'Océanographie Physique et Spatiale (LOPS), IUEM, Plouzané, France

${ }^{3}$ Ifremer, Univ. Brest, CNRS, IRD, Laboratoire d'Océanographie Physique et Spatiale (LOPS), IUEM,

Plouzané, France

${ }^{4}$ P.P Shirshov Institute of Oceanology, Moscow, Russia

${ }^{5}$ CNRS, Univ. Brest, IRD, Ifremer, Laboratoire d'Océanographie Physique et Spatiale (LOPS), IUEM, Brest, France

${ }^{6}$ Instituto de Investigaciones Marinas, IIM-CSIC, 36208 Vigo, Spain

* Corresponding author : Nathalie Daniault
}

\begin{abstract}
:
The decadal mean circulation in the northern North Atlantic was assessed for the early 21st century from repeated ship-based measurements along the Greenland-Portugal OVIDE line, from satellite altimetry and from earlier reported transports across $59.5^{\circ} \mathrm{N}$ and at the Greenland-Scotland sills. The remarkable quantitative agreement between all data sets allowed us to draw circulation pathways with a high level of confidence. The North Atlantic Current (NAC) system is composed of three main branches, referred to as the northern, central and southern branches, which were traced from the Mid-Atlantic Ridge (MAR), to the Irminger Sea, the Greenland-Scotland Ridge and the subtropical gyre. At OVIDE, the northern and central branches of the NAC fill the whole water column and their top-to-bottom integrated transports were estimated at $11.0 \pm 3 \mathrm{~Sv}$ and $14.2 \pm 6.4 \mathrm{~Sv}$ ( $1 \mathrm{~Sv}=106 \mathrm{~m} 3 \mathrm{~s}-1$ ), respectively. Those two branches feed the cyclonic circulation in the Iceland Basin and the flow over the Reykjanes Ridge into the Irminger Sea. This cross-ridge flow was estimated at $11.3 \pm 4.2 \mathrm{~Sv}$ westward, north of $58.5^{\circ} \mathrm{N}$. The southern NAC branch is strongly surface-intensified and most of its top-to-bottom integrated transport, estimated at $16.6 \pm 2 \mathrm{~Sv}$, is found in the upper layer. It is composed of two parts: the northern part contributes to the flow over the Rockall Plateau and through the Rockall Trough towards the Iceland-Scotland Ridge; the southern part feeds the anticyclonic circulation towards the subtropical gyre. Summing over the three NAC branches, the top-to-bottom transport of the NAC across OVIDE was estimated at $41.8 \pm 3.7 \mathrm{~Sv}$. Because of the surface-intensification of the southern NAC branch, the intermediate water is transported to the northeast Atlantic mostly by the northern and central branches of the NAC $(11.9 \pm 1.8 \mathrm{~Sv}$ eastward). This water circulates cyclonically in the Iceland Basin and anticyclonically in the West European Basin, with similar transport intensities. In the deep layer of the Iceland Basin, Iceland-Scotland Overflow Water (ISOW) spreads southwestward along three
\end{abstract}


pathways on the eastern flank of the Reykjanes Ridge. The associated transport was estimated at $3.2 \pm$ 0.4 Sv. The two shallowest pathways turn around the Reykjanes Ridge towards the Irminger Sea where they head northward. A northeastward transport of deep water is observed in the deep extension of the northern and central branches of the NAC, east of the MAR. In the Irminger Sea our transport estimates for the Irminger Current, Irminger Gyre, East Greenland Irminger Current and Deep Western Boundary Current are in line with previous work.

\section{Highlights}

- Northern North Atlantic ocean circulation is quantified. Circulation schemes for the upper, intermediate and deep layers are derived. New pathways for the North Atlantic Current branches are proposed. The fate of the intermediate water flow across the Mid-Atlantic Ridge is identified. Three veins of Iceland Scotland Overflow Water are found in the Iceland Basin.

\section{List of acronyms}

$\begin{array}{ll}\text { ABR } & \text { Azores-Biscay Rise } \\ \text { AVISO } & \text { Archiving, Validation, and Interpretation of Satellite Oceanographic } \\ \text { BFZ } & \text { Bight Fracture Zone } \\ \text { CATARINA } & \text { Carbon Transport and Acidification Rate in the North Atlantic } \\ \text { CGFZ } & \text { Charlie-Gibbs Fracture Zone } \\ \text { CPIES } & \text { Current and Pressure recording Inverted Echo Sounder } \\ \text { CTD } & \text { Conductivity-Temperature-Depth } \\ \text { DLC } & \text { Deep Labrador Current } \\ \text { DSOW } & \text { Denmark Strait Overflow Water } \\ \text { DWBC } & \text { Deep Western Boundary Current } \\ \text { EGC } & \text { East Greenland Current } \\ \text { EGIC } & \text { East Greenland Irminger Current } \\ \text { ESM } & \text { Eriador Seamount } \\ \text { ENACW } & \text { East North Atlantic Central Water } \\ \text { ERRC } & \text { East Reykjanes Ridge Current } \\ \text { FFZ } & \text { Faraday Fracture Zone } \\ \text { IAP } & \text { Iberian Abyssal Plain } \\ \text { IC } & \text { Irminger Current } \\ \text { IG } & \text { Irminger Gyre } \\ \text { ISOW } & \text { Iceland-Scotland Overflow Water } \\ \text { ISW } & \text { Icelandic Slope Water } \\ \text { LADCP } & \text { Lowered Acoustic Doppler Current Profiler } \\ \text { LC } & \text { Labrador Current } \\ \text { LSW } & \text { Labrador Sea Water } \\ \text { MAR } & \text { Mid-Atlantic Ridge } \\ \text { MC } & \text { Maury Channel } \\ \text { MFZ } & \text { Maxwell Fracture Zone } \\ \text { MOC } & \text { Meridional Overturning Circulation } \\ \text { MW } & \text { Mediterranean Water } \\ \text { NAC } & \text { North Atlantic Current } \\ \text { NACW } & \text { North Atlantic Central Water } \\ \text { NAO } & \text { North Atlantic Oscillation } \\ \text { NEADW } & \text { North East Atlantic Deep Water } \\ \text { NWC } & \text { North West Corner, region southeast of Newfoundland } \\ \text { OVIDE } & \text { Observatoire de la variabilité interannuelle et décennale en Atlantique Nord } \\ & \end{array}$




$\begin{array}{ll}\text { RAW } & \text { Recirculating Atlantic Water } \\ \text { RR } & \text { Reykjanes Ridge } \\ \text { RT } & \text { Rockall Trough } \\ \text { SADCP } & \text { Ship-mounted Acoustic Doppler Current Profiler } \\ \text { SAF } & \text { Subarctic Front } \\ \text { SAIW } & \text { Subarctic Intermediate Water } \\ \text { SPG } & \text { Subpolar Gyre } \\ \text { SPMW } & \text { Subpolar Mode Water } \\ \text { SPNA } & \text { Subpolar North Atlantic Ocean } \\ \text { STG } & \text { Subtropical Gyre } \\ \text { STNA } & \text { Subtropical North Atlantic Ocean } \\ \text { WBC } & \text { Western Boundary Current } \\ \text { WGC } & \text { West Greenland Current }\end{array}$




\section{INTRODUCTION}

The subpolar gyre (SPG) of the North Atlantic Ocean plays an important role in the climate system by setting the properties of the water masses constituting the lower limb of the meridional overturning circulation (MOC). Indeed, it is the place of gradual transformation of the subtropical water carried northward in the upper North Atlantic Current (NAC) into Subpolar Mode Water (SPMW) (McCartney and Talley, 1982; Brambilla and Talley, 2008).

The densest variety of SPMW is the Labrador Sea Water (LSW) that, along with the overflow waters from the Nordic Seas, is the main constituent of the cold branch of the MOC. The SPG is also the most important site of anthropogenic carbon dioxide storage (Pérez et al., 2010;

Pérez et al., 2013; Khatiwala et al., 2013). The main features of the subpolar North Atlantic Ocean (SPNA) circulation are shown in Figure 1. This sketch was adapted from GarcíaIbáñez et al. (2015) by including recent observations on the NAC (e.g. Roessler et al., 2015) and some of the results of the present study.

As sketched in Figure 1, the waters of subtropical origin carried northward by the NAC are joined by waters of subpolar origin in the Northwest Corner region where those waters mix together (Dutkiewicz et al., 2001; de Boisséson et al., 2010), illustrating the dual role of the NAC in being both the upper limb of the MOC, connecting subtropical and subpolar latitudes, and the southern limb of the cyclonic subpolar gyre. Downstream, the NAC flows eastward in several branches (Rhein et al., 2011; Roessler et al., 2015) with circulation pathways strongly constrained by bathymetry. At the MAR, three branches of the NAC have been reported to be quasi-locked to the Charlie-Gibbs Fracture Zone (CGFZ, $\left.52^{\circ}-53^{\circ} \mathrm{N}\right)$, the Faraday Fracture Zone (FFZ, $\left.50^{\circ}-51^{\circ} \mathrm{N}\right)$ and the Maxwell Fracture Zone (MFZ, $\left.48^{\circ} \mathrm{N}\right)(\mathrm{e} . \mathrm{g}$. Bower and von Appen, 2008; Harvey and Arhan, 1988; Sy et al., 1992; Pollard et al., 2004).

The NAC branches crossing the MAR at the CGFZ and FFZ have been reported to head northeastward to the central Iceland Basin, the Rockall Plateau and the Rockall Trough 
(Flatau et al., 2003; Orvik and Niiler, 2002; Pollard et al., 2004; Volkov and van Aken, 2005; Hakkinen and Rhines, 2009), while the MFZ branch has been reported to veer southward in the West European Basin (Paillet and Mercier, 1997; Figure 1). Overall, the circulation is cyclonic north of the NAC and anticyclonic south of the NAC. The anticyclonic flow around the Reykjanes Ridge (Bower et al., 2002) continues into the Irminger Sea and joins the EastGreenland Irminger Current (EGIC) off the coast of Greenland (Lherminier et al., 2007). The cyclonic circulation in the Irminger Sea - the Irminger gyre - was extensively studied by Våge et al. (2011).

Despite the growing number of observations acquired over recent decades in the SPNA, certain features of the SPNA circulation remain poorly documented. For example, as reviewed by Roessler (2013), the NAC transport estimates east of the MAR are few (Yaremchuk et al., 2001; Lherminier et al. 2007, 2010; Gourcuff et al., 2011). They strongly depend on the lateral and vertical limits used to define the NAC and on the temporal and spatial resolution of the data. Transports around and over the Reykjanes Ridge are debated: combining hydrographic sections and current measurements, Lherminier et al. (2010) and Sarafanov et al. (2012) suggested a transport of $\sim 10 \mathrm{~Sv}$ from the Iceland Basin to the Irminger Sea north of $\sim 59^{\circ} \mathrm{N}$ while, analyzing repeated SADCP sections and satellite altimetry, Chafik et al. (2014) concluded to a very little transport in the $0-400 \mathrm{~m}$ layer north of $\sim 60^{\circ} \mathrm{N}$.

Nevertheless, robust benchmarks based on observations are required for the evaluation of ocean general circulation models that show contrasting representations of the circulation in the SPNA. Examples of the difficulty for eddy-resolving $\left(1 / 6^{\circ}-1 / 10^{\circ}\right)$ models to correctly represent the circulation are found in the Northwest Corner region, southeast of Newfoundland (Worthington, 1976), and along the pathways followed by the warm and salty subtropical water transported by the NAC to the Irminger Sea (Treguier et al., 2005; Rattan et al., 2010). 


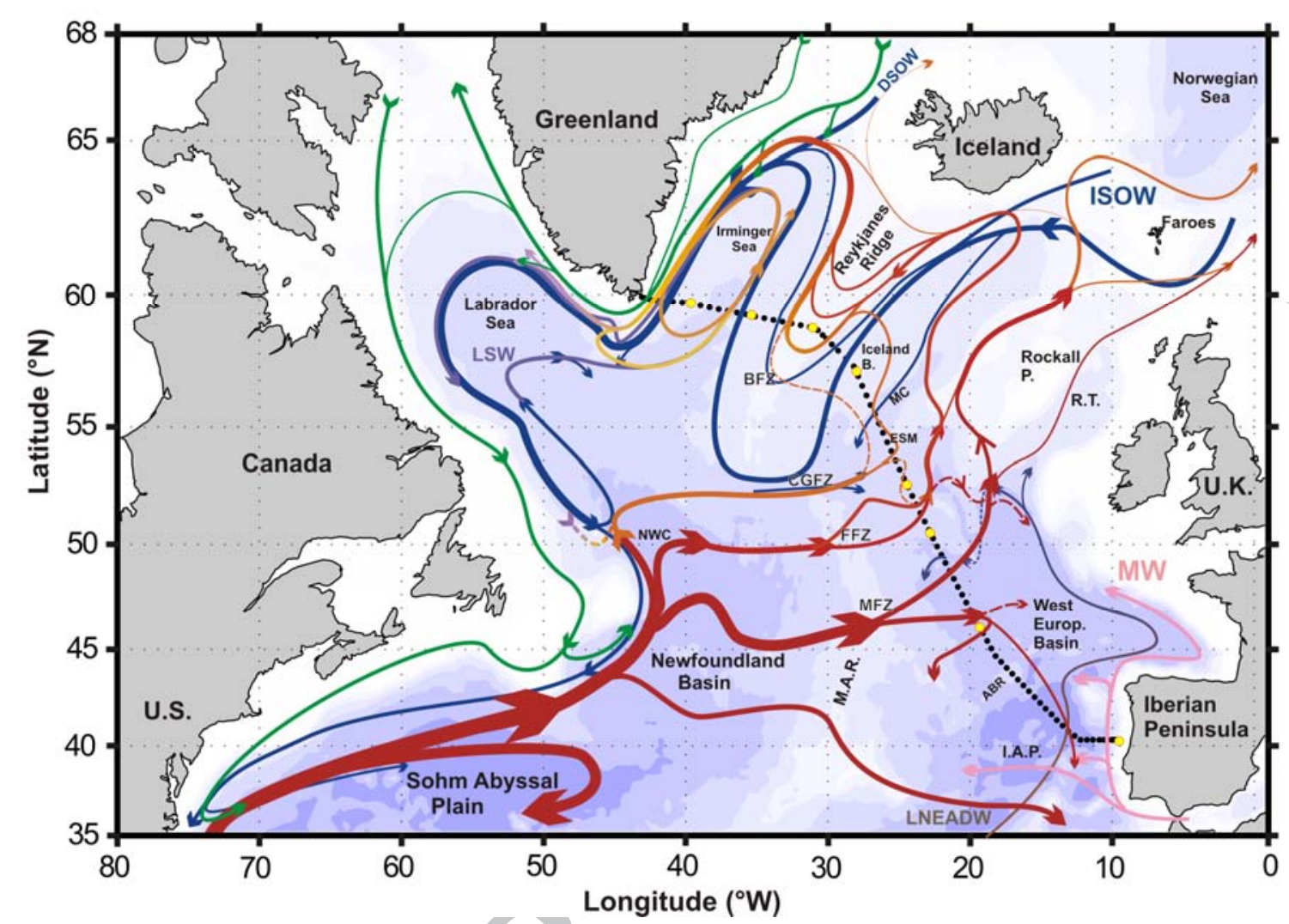

Figure 1: Schematic diagram of the large-scale circulation adapted from (García-Ibáñez et al., 2015) by adding a refined scheme for the NAC branches based on the results of this study (see text). Bathymetry is plotted in color with color change at $100 \mathrm{~m}$, at $1000 \mathrm{~m}$ and every $1000 \mathrm{~m}$ below $1000 \mathrm{~m}$. The locations of the OVIDE hydrographic stations are indicated by black dots. Yellow dots mark the limits of the regions used for the transport computations. The main topographical features of the Subpolar North Atlantic are labeled: ABR: Azores-Biscay Rise, Bight Fracture Zone (BFZ), Charlie-Gibbs Fracture Zone (CGFZ), Faraday Fracture Zone (FFZ), Maxwell Fracture Zone (MFZ), Mid-Atlantic Ridge (M.A.R.), Iberian Abyssal Plain (I.A.P.), Northwest Corner (NWC), Rockall Trough (RT), Rockall Plateau (Rockall P.) and Maury Channel (MC). The main water masses are indicated: Denmark Strait Overflow Water (DSOW), Iceland-Scotland Overflow Water (ISOW), Labrador Sea Water (LSW), Mediterranean Water (MW), and Lower North East Atlantic Deep Water (LNEADW).

In this study, we estimated and analyzed the time-averaged circulation between

Greenland and Portugal computed from 6 summer repeats of the OVIDE (Observatoire de la

Variabilité Interannuelle à Décennale) section, carried out over the 2002-2012 decade (Figure

1), and we analyzed associated circulation patterns based on a larger data set. This study 
complements previous analyses by Våge et al. (2011), Sarafanov et al.(2012) and Chafik et al. (2014) that documented the time-averaged circulation over different time spans at $59-60^{\circ} \mathrm{N}$. This article focuses first on the identification of the origin and fate of the branches of the NAC intersected by the OVIDE section and the quantification of their transports. Second, we analyze the circulation and transports around and across the Reykjanes Ridge and third we discuss the Irminger Sea circulation. We finally discuss coherent circulation schemes synthesizing flow pathways and transports. The time-averaged circulation for $2002-2012$ across OVIDE was obtained from summer cruises only and the limitations of our study are the same as those discussed in detail by Sarafanov et al. (2012). Nonetheless, no abrupt circulation shift similar to that observed in the mid-1990s was reported during 2002-2012. During this decade, the North Atlantic Oscillation (NAO), which is the main atmospheric driver of the SPNA variability (see e.g. Sarafanov, 2009 for a discussion on the SPNA response to NAO), showed an interannual variability but no clear trend and averaged out to zero over the period. During 2002-2012, the surface circulation and the MOC in the SPNA were consistently weaker and the SPMW was consistently warmer and saltier than in the early 1990s (Hakkinen and Rhines, 2009; Mercier et al., 2015; Thierry et al., 2008; de Jong et al., 2012). Averaging over a 10-year period is also consistent with the frequency spectra of the MOC and Deep Western Boundary Current (DWBC) in the SPNA that show a significant quasi-decadal signal, suggesting a relation with the quasi-decadal mode of the NAO (Mercier et al., 2015; Kartstensen et al., Pers. Comm.).

This article is organized as follows. After presenting the data and methods in Section 2, we discuss the time-averaged velocity and transport estimates across OVIDE in Section 3. Then, in Section 4 we discuss the results and present schemes synthesizing the circulation based on a larger data set. Section 5 concludes the article. 


\section{DATA AND METHODS}

\subsection{OVIDE hydrographic and ADCP measurements}

The hydrographic and velocity data source is the WOCE A25 Greenland-Portugal OVIDE section carried out every other year between 2002 and 2012 in the framework of the OVIDE and CATARINA (Carbon Transport and Acidification Rate in the North Atlantic) projects (Table 1, Figure 1). Each section consisted of about ninety CTD (Conductivity Temperature Depth) stations carried out with a nominal spacing of $45 \mathrm{~km}$ that was reduced to $35 \mathrm{~km}$ in the Irminger Sea and $25 \mathrm{~km}$ or less over steep topographic features and at continental slopes and margins. The accuracy of the temperature, salinity and pressure measurements are better than $0.002^{\circ} \mathrm{C}, 0.002$ and $1 \mathrm{dbar}$ respectively (e.g. Branellec and Lherminier, 2009). During each cruise ship-mounted acoustic Doppler current profiler (SADCP) measurements were acquired. A high level of quality was achieved for the SADCP velocity data by correcting for the misalignment of the orientation of the beams relative to the vessel axis and systematic bias in navigation heading (Lherminier et al., 2007).

The rosette was equipped with a $150 \mathrm{kHz}$ downward looking and a $300 \mathrm{kHz}$ upwardlooking RD Instruments lowered acoustic Doppler current profiler (LADCP), except in 2012 where two $300 \mathrm{kHz}$ LADCP were used. Both LADCPs returned data at every station. The LADCP data were processed using the inverse method developed by Visbeck (2002). The reader is referred to Lherminier et al. (2007) for a detailed presentation of the LADCP data processing. The barotropic tides were removed from the SADCP and the LADCP data using the TPXO Global Tidal solutions (Egbert and Erofeeva, 2002). Overall, the LADCP velocity error is less than $0.03 \mathrm{~m} \mathrm{~s}^{-1}$ in agreement with Thurnherr (2010). 
Project Research Vessel

June 10 - July 12, 2002

June 4 - July 7, 2004

May 21 - June 28, 2006

June 10 - July 10, 2008

June 8 - July 7, 2010

June 23 - August 12, 2012

OVIDE

OVIDE

OVIDE

OVIDE

OVIDE

CATARINA
Thalassa

Thalassa

M.S. Merian

Thalassa

Thalassa

Sarmiento de Gamboa
Chief Scientist

Herlé Mercier

Thierry Huck

Pascale Lherminier

Bruno Ferron

Virginie Thierry

Aida F. Ríos

Table 1: Hydrographic cruises

\subsection{Inverse modeling}

The measurements along the OVIDE section were presented and analyzed in terms of circulation variability by Lherminier et al. (2007), Lherminier et al. (2010), Gourcuff et al. (2011) and Mercier et al. (2015). In those studies, estimates of the absolute geostrophic velocity fields orthogonal to the section were obtained with an inverse model that combined the hydrography and SADCP data with an overall volume conservation constraint of $1 \pm 3 \mathrm{~Sv}$ across the section (Lherminier et al., 2007). In the surface layer, the velocity field includes an Ekman velocity component in addition to the geostrophic component. The 2012 OVIDE data, which are unpublished data, were processed with the same inverse model set-up as for previous analyses. The 2012 surface-to-bottom integrated transport accumulated southeastward from Greenland (the barotropic streamfunction) is, for further reference, plotted in Figure 2 along with estimates for previous years. 


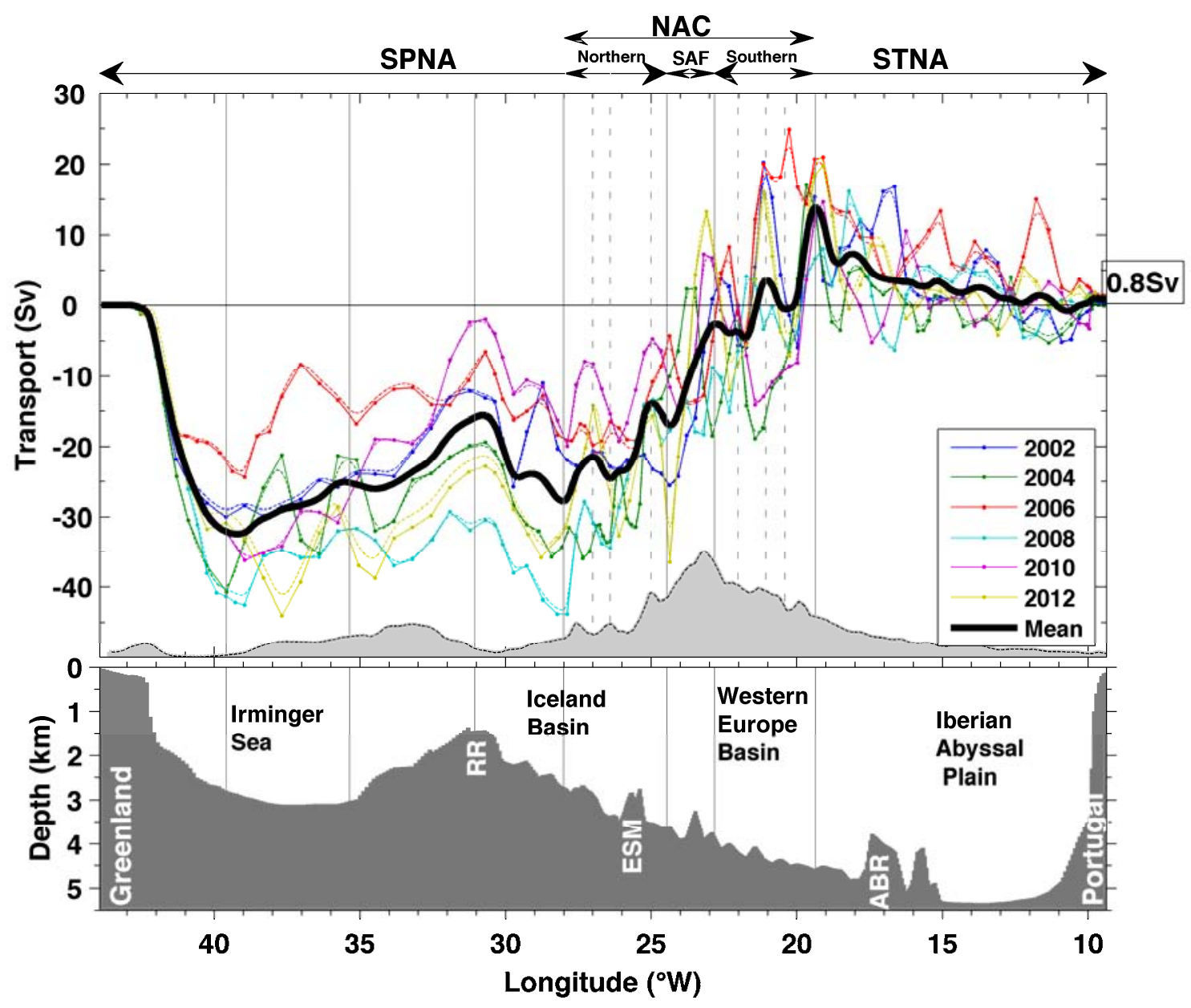

Figure 2: Upper panel: Cumulative sums of the depth-integrated transports (Sv) from Greenland to Portugal or barotropic streamfunctions for the 6 occupations of the OVIDE section. The heavy black line represents the 2002-2012 mean barotropic streamfunction. The 2002-2012 mean net transport across the section is $0.8 \mathrm{~Sv}$. The continuous and dotted lines represent the streamfunctions before and after projection on the reference track (see text for details). The gray patch at the bottom of the upper panel is proportional to the surface eddy kinetic energy estimated from altimetry data. The thin vertical gray lines locate the isotachs of zero velocity used to delimit regions for transport computations in Figure 5 and Table 3. The dashed gray lines locate the NAC branches subdivisions used in Table 3. The double arrows at the top delimit the domains intersected by the OVIDE section. SPNA and STNA stand for subpolar North Atlantic and subtropical North Atlantic. Northern, SAF and Southern refer respectively to the NAC northern branch, the Sub-Arctic Front (NAC central branch) and the NAC southern branch. Lower panel: Bathymetry along OVIDE. The bathymetry data were acquired by the N/O Thalassa sounder in 2004 and sub-sampled every $7 \mathrm{~km}$. The main topographic features are indicated: Reykjanes Ridge (RR), Eriador Seamount (ESM) and Azores-Biscay Ridge (ABR). 


\subsection{Gridding and averaging}

The same stations were occupied during each of the 6 OVIDE cruises except when bad weather or the presence of sea-ice on the Greenland shelf forced the ship to deviate from the nominal cruise plan. Because these deviations prevented a straightforward averaging of the data, we implemented Våge et al. (2011) procedure that was designed to cope with such difficulty. We defined a reference track and moved all the stations located apart on it. Then, we linearly interpolated the station data on a regular horizontal $\times$ vertical grid before averaging the data over time. The method is detailed below.

The reference track followed the 2004 OVIDE cruise track except on the Greenland continental shelf, west of $41^{\circ} \mathrm{W}$, where it followed a line of best fit, in the least-squares sense, computed from the locations of available stations. The locations of the stations on the reference track were determined by minimizing the distances between the original locations and the reference track. In addition, if for a station the difference in bottom depths between the original and new locations exceeded 5\%, the new station location was moved along the reference track until the bottom depth matched the original bottom depth plus or minus $5 \%$. The bathymetry along the reference track was that acquired by the N/O Thalassa sounder in 2004 except over the Greenland shelf where we used Sandwell et al. (2006) bathymetry. For $95 \%$ of the stations the displacement was less than $2 \mathrm{~km}$. The largest displacements occurred on the Greenland shelf.

The temperature, salinity and velocity profiles were assigned to the new locations. To conserve the transports, the inverse model velocities displaced on the reference track were multiplied by the ratio of the inter-station area calculated after displacement to that before displacement. This small correction was essential to ensure mass conservation across the individual sections. In figure 2, we compare the barotropic streamfunction computed from the 
inverse model original velocities to that computed with the velocities displaced on the reference track for the 6 OVIDE cruises, showing that changes in transports induced by the displacements are small.

\begin{tabular}{lll}
\hline Layer & Limits & Water masses \\
& & \\
\hline Upper MOC & $\sigma_{1}<32.15$ as in [Mercier et al., 2015] & Arctic Water \\
& & RAW \\
& & SPMW \\
& & SAIW \\
& & NACW \\
& & Upper MW \\
\hline Intermediate & $\sigma_{1}=32.15$ to $\sigma_{0}=27.80$ or $\sigma_{2}=36.94$ & LSW \\
& (southeast of the southern NAC & ISW \\
& branch) & Deep MW \\
\hline Upper Deep Water & $\sigma_{0}=27.80$ or $\sigma_{2}=36.94$ (southeast of & ISOW \\
& the southern NAC branch) to & NEADW \\
& $\sigma_{4}=45.85$ & \\
\hline Lower Deep Water & $\sigma_{4}>45.85$ & DSOW \\
& & Lower NEADW \\
\hline
\end{tabular}

Table 2: Limits of the layers and water masses they encompass. Water mass acronyms are defined at the beginning of the article.

Once displaced onto the reference track, the temperature, salinity and velocity data of the individual cruises were linearly interpolated on the same $7 \mathrm{~km}$ horizontal $\times 1 \mathrm{~m}$ vertical resolution grid. The vertical sections of the temperature, salinity and velocity in Figures 3 and 4 were obtained by time averaging at grid points. The mean transports were estimated by spatial integration of the mean velocity fields. The standard errors on the mean transports were estimated as $\sigma / \sqrt{N}$ where $\sigma$ is the standard deviation of the velocity field computed from the $\mathrm{N}=6$ repeats of the OVIDE section. The mean transports presented in Figure 5 are given for selected regions delimited by isotachs of zero velocity and selected layers delimited by isopycnals (see also Table 2). 


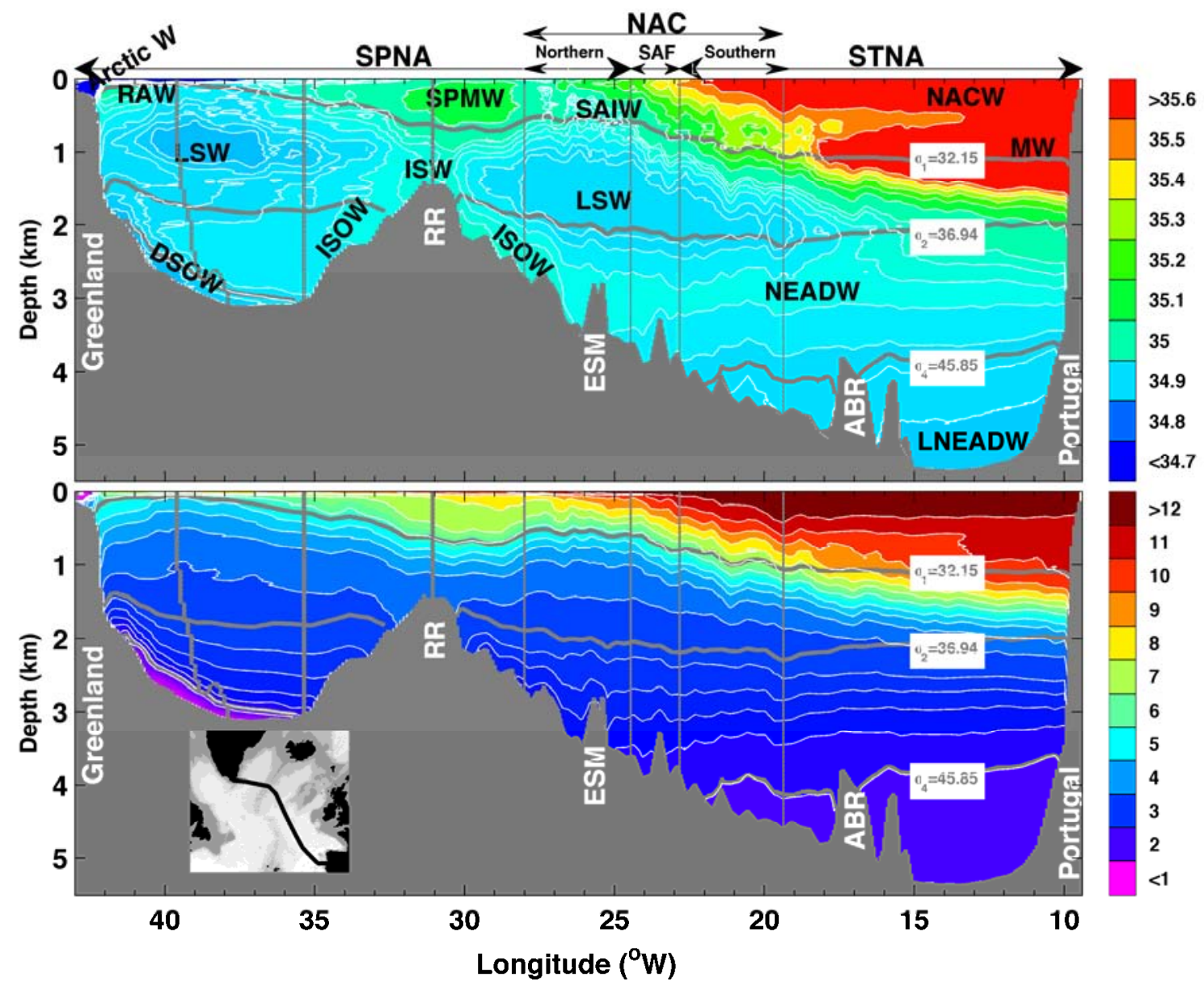

Figure 3: The 2002-2012 mean potential temperature in ${ }^{\circ} \mathrm{C}$ (lower panel) and salinity (upper panel) along the OVIDE section (see insert). The vertical and horizontal continuous gray lines delimit the regions and isopycnal layers used for transport computations in Figure 5. The main topographic features are indicated. Water mass acronyms are defined at the beginning of the article. 


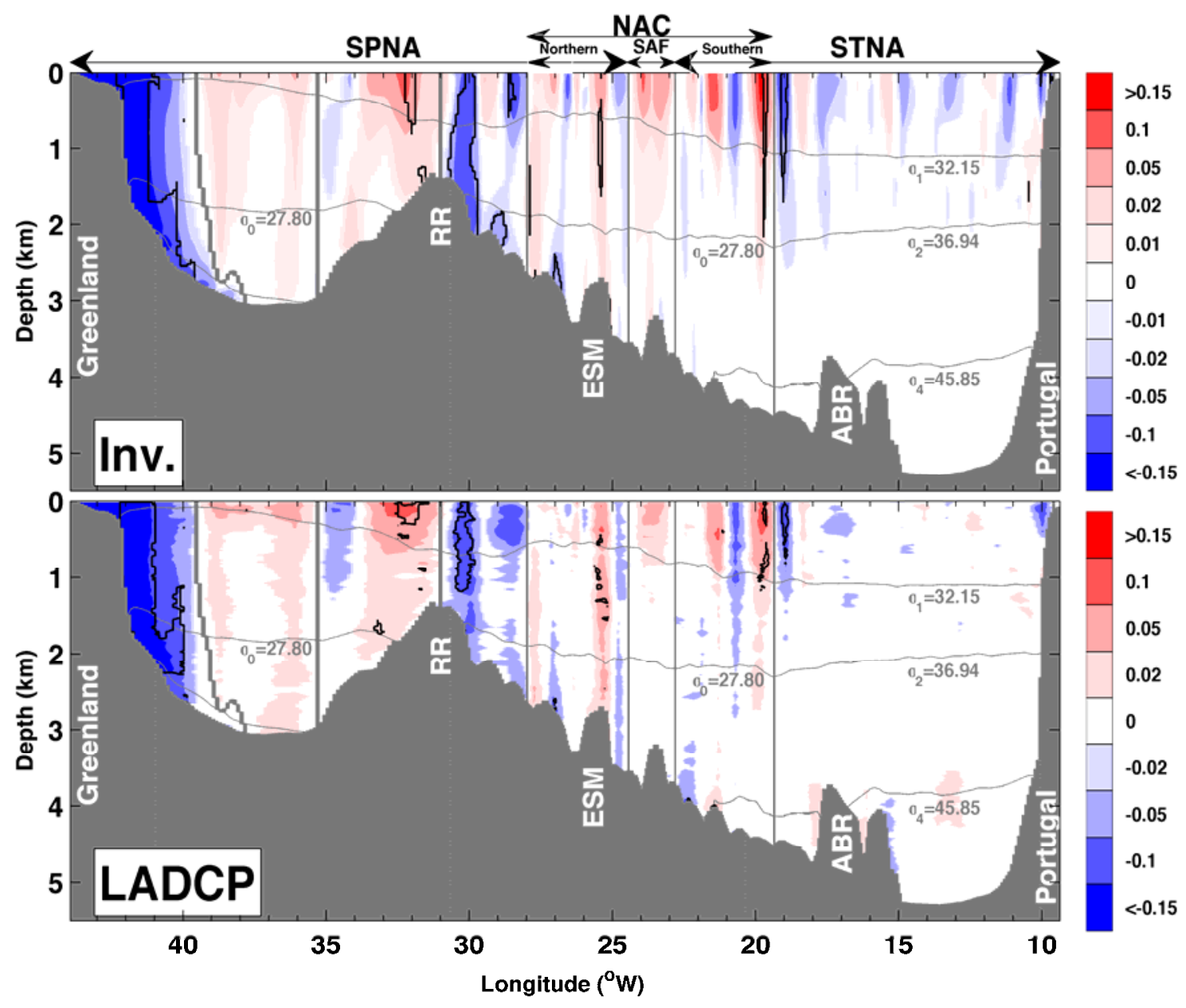

Figure 4: The 2002-2012 mean velocities $\left(\mathrm{m} \mathrm{s}^{-1}\right.$ ) orthogonal to the OVIDE section computed from the inversion-derived velocities (upper panel) and the LADCP velocities (lower panel). Positive velocities indicate that the meridional component of the current is northward. The continuous gray lines delimit the regions and layers used for the transport computations. Black contours delimit regions where the velocity was found to be in the same direction for all repeats of the OVIDE section. Those circulation features are referred to as permanent circulation features. Topographic abbreviations, region and layer limits are as in Figure 3. White areas are where the absolute velocity is less than $0.01 \mathrm{~m} \mathrm{~s}^{-1}$ for inversion and $0.02 \mathrm{~m} \mathrm{~s}^{-1}$ for LADCP. 


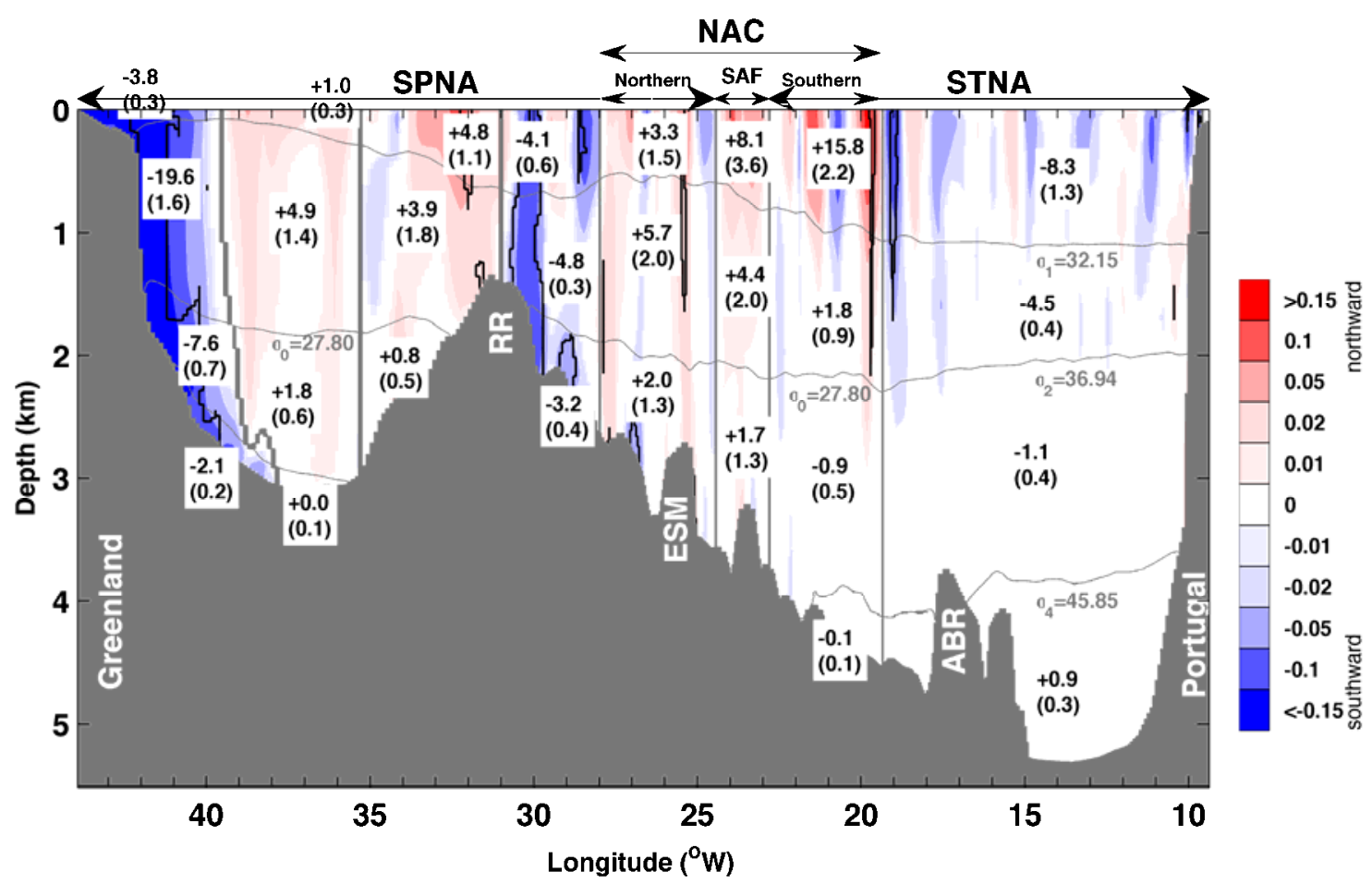

Figure 5: The 2002-2012 mean velocities $\left(\mathrm{m} \mathrm{s}^{-1}\right)$ orthogonal to the OVIDE section computed from the inversion-derived velocities. Black numbers are the 2002-2012 mean transports (in Sv) across the OVIDE section. Standard errors $(\sigma / \sqrt{N})$ are indicated in parenthesis. Topographic abbreviations, region and layer limits are as in Figure 3. The continuous gray lines delimit the regions and layers used for the transport computations. The layers are defined in Table 2.

\subsection{Evaluation of the velocity fields}

The mean velocity fields were calculated from the inverse model velocity and the LADCP velocity fields, independently (Figure 4). Although both time-averaged velocity fields show the same mesoscale and large-scale structures, the velocity field from the LADCP contains more energy at small spatial scales than the geostrophic inverse model velocity (see Lherminier et al. (2007) for a discussion of this point). Because of this noise, weak currents are not resolved by the LADCP. This is especially true in the STNA where the LADCP velocities do not show all the patterns resolved by the inverse model. Nonetheless, the two time-averaged velocity fields are correlated $\left(\mathrm{V}_{\text {ladcp }}=0.9 \mathrm{~V}_{\text {inversion }}+6 \times 10^{-4} \mathrm{~m} \mathrm{~s}^{-1}\right.$, p-value $<$ $\left.10^{-3}\right)$ and the root mean square difference between the two fields is low $\left(0.014 \mathrm{~m} \mathrm{~s}^{-1}\right)$. The 
small bias $\left(6 \times 10^{-4} \mathrm{~m} \mathrm{~s}^{-1}\right)$ between the two velocity fields results in a large difference in the net transport across OVIDE: The latter was estimated at $0.8 \mathrm{~Sv}$ based on inverse model velocities and at $8 \mathrm{~Sv}$ based on LADCP velocities. The unrealistic net transport obtained from the LADCP data is possibly due to the incomplete filtering of local and ageostrophic velocity components when averaging the LADCP velocities over 6 sections only. Accordingly, we decided to base the discussion of the transports solely on inverse model velocities and to use the LADCP data as an additional independent source of information on the mean circulation.

\subsection{Altimetry}

Altimetry was used to place estimates of the sea-surface velocities at OVIDE within a wider spatial context. We used the delayed-time merged global ocean $14^{\circ}$ gridded surface geostrophic velocity products produced by Ssalto/Duacs and distributed by Aviso (Archiving, Validation, and Interpretation of Satellite Oceanographic data center) with support from CNES (SSALTO/Duacs L4 product, http://www.aviso.altimetry.fr/duacs/). These daily surface velocity fields were derived from measurements of sea surface height using all available satellites and CNES-CLS 13 mean dynamic topography (produced by CLS Space Oceanography Division and distributed by Aviso). Time-average fields of surface velocity over all summers (June-September) of 2002-2012 were subsequently produced for comparison with the 2002-2012 time-averaged surface circulation computed from the OVIDE data (Figure 6). 


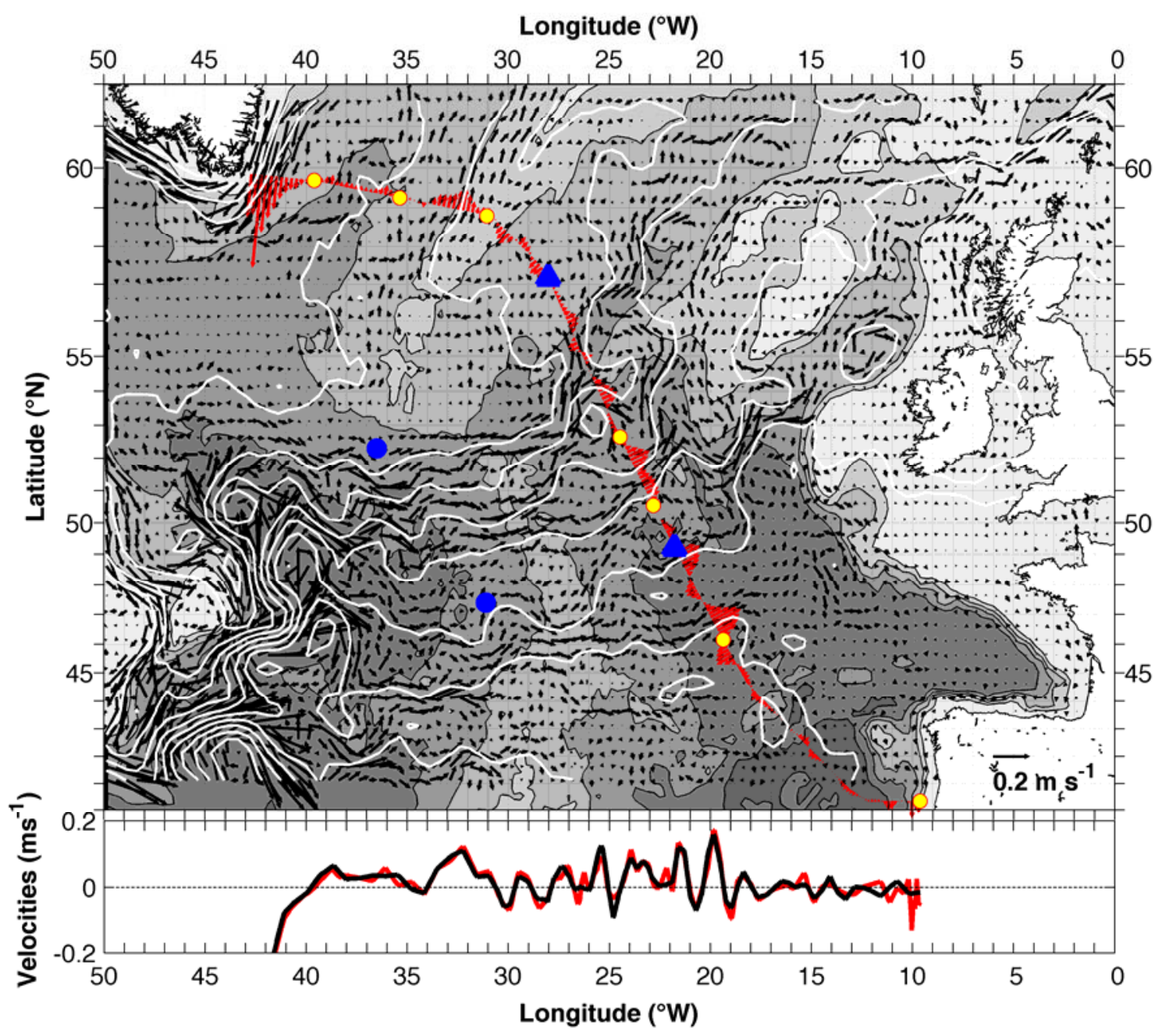

Figure 6:Upper panel: The 2002-2012 mean summer sea-surface velocities computed from the AVISO dataset (black vectors) and the 2002-2012 mean inversion-derived surface velocities orthogonal to the OVIDE line (red vectors). Contours of the mean summer dynamic topography from AVISO are plotted in white with a contour interval of $0.1 \mathrm{~m}$. A velocity scale, used to plot the black and red arrows, is indicated at the bottom right corner. Continuous black lines are isobaths. Yellow dots correspond to the surface limits of the regions shown in Figures 2-5, 7 and Table 3. Blue dots are the limits of Roessler et al. (2015) array and blue triangles are the equivalent locations at OVIDE. Lower panel: The 2002-2012 mean summer surface velocities ( $\mathrm{m} \mathrm{s}^{-1}$ ) orthogonal to the OVIDE section computed from the inversion (red line) compared to those computed from AVISO dataset (black line).

\section{MEAN TRANSPORTS ACROSS THE OVIDE SECTION FOR 2002-2012}

This section is organized as follows. We first describe the NAC and its branches (section 3.1) and present their transports (section 3.2). After a brief description of the 
anticyclonic circulation south of the NAC (section 3.3) we focus on the transports around the Reykjanes Ridge (section 3.4) and, finally, we discuss the western boundary current system and the Irminger Gyre (section 3.5). The analysis of the averaged fields (Figures 3 and 4) distinguishes four isopycnal layers named, from surface to bottom, the upper MOC layer, the intermediate layer, the upper deep layer and the lower deep layer (the upper and lower deep layers are sometimes merged and referred to as the deep layer). The limits of the layers, which are similar to those found in the literature (see e.g. Sarafanov et al., 2012), and the water masses they encompass are indicated in Table 2.

\subsection{The NAC description}

The NAC branches are embedded in an energetic eddy field (see the distribution of surface eddy kinetic energy in Figure 2), which challenges the identification, in synoptic fields, of an unequivocal relationship between the NAC branches in the eastern basin and those at the MAR. However, as discussed in the following paragraphs, connections can be identified in the time-averaged fields derived from OVIDE.

We compare, in Figure 6, the mean surface geostrophic velocities across the OVIDE section with the time-averaged surface velocities derived from altimetry for the summers of 2002-2012. Remarkably, the main circulation features are collocated in the OVIDE and altimetry data sets. Note that using the 2002-2012 annual mean altimetry-derived velocities would not change this result. The root mean square difference between the two data sets is small $\left(0.035 \mathrm{~m} \mathrm{~s}^{-1}\right)$, in accordance with the results previously obtained by Gourcuff et al. (2011). The time-averaged altimetry-derived velocities (Figure 6) show that, at the seasurface, the NAC crosses the MAR along three pathways at about $52.5^{\circ} \mathrm{N}, 31.5^{\circ} \mathrm{W}$ (CGFZ), $50^{\circ} \mathrm{N}, 29^{\circ} \mathrm{W}(\mathrm{FFZ})$ and $46.5^{\circ} \mathrm{N}, 27^{\circ} \mathrm{W}$ (MFZ) in line with Bower and von Appen (2008) (see the locations in Figure 1). Those three branches are referred hereinafter as the northern, 
central and southern branches of the NAC. The central branch corresponds to the Subarctic Front (SAF), which was defined by Bersch (2002) as the sharp salinity front with a salinity value of about 35.2 at its center (Figure 7). In the eastern basin, circulation features associated with the NAC clearly emerge in the time-averaged velocity field (Figure 6; see also Figure 1 for a synthesis). The northern NAC branch is observed at OVIDE near Eriador Seamount. Downstream, this branch flows parallel to the OVIDE section and crosses the Maury Channel before turning northeast. The central NAC branch crosses OVIDE between $50.5^{\circ} \mathrm{N}, 23^{\circ} \mathrm{W}$ and $52.5^{\circ} \mathrm{N}, 25^{\circ} \mathrm{W}$ and, for the most part, continues around the Rockall Plateau. The southern NAC branch splits into two branches west of OVIDE. One branch crosses OVIDE at $48.5^{\circ} \mathrm{N}$, $21.5^{\circ} \mathrm{W}$ and continues towards the Rockall Trough and the Rockall Plateau (to our knowledge, this feature has not been previously discussed in the literature). The other branch crosses OVIDE at $46.1^{\circ} \mathrm{N}, 19.4^{\circ} \mathrm{W}$ and then circulates anticyclonically in the Western European Basin towards the subtropical North Atlantic Ocean (STNA). 


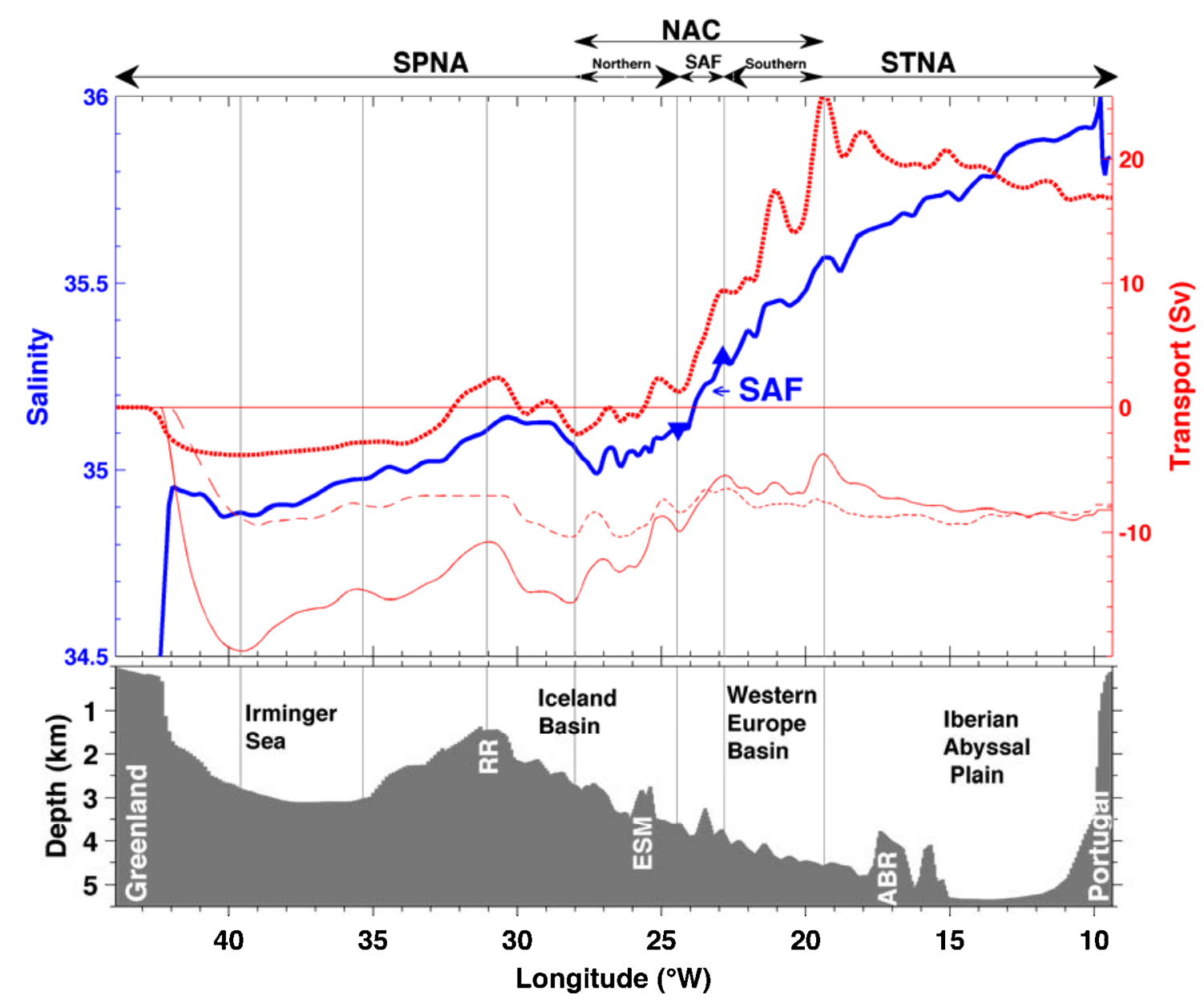

Figure 7: Upper panel: Cumulative sum from Greenland to Portugal of the transport in the upper layer ( $\mathrm{Sv}$, thick dotted red line), the intermediate layer (thin red line), the deep layer (thin dashed red line); vertically averaged salinity in the upper layer (blue line). Topographic abbreviations are the same as in Figure 3. Vertical gray lines delimit the regions for which the transports are reported in Figure 5. Blue triangles delimit the Sub-Arctic Front (SAF) or central NAC branch. Lower panel: Bathymetry along the OVIDE section.

\subsection{The NAC transports}

East of the MAR, there is no unique definition of the geographical limits of the NAC

that could be used for the computation of the NAC transport. We thus relied on the barotropic streamfunction (Figure 2) and defined the NAC as being the wide northeastward flow in between the relative minimum of the streamfunction at $57.2^{\circ} \mathrm{N}, 28^{\circ} \mathrm{W}$, which corresponds to the center of the Iceland Basin cyclonic circulation, and the maximum of the streamfunction 
at $46.1^{\circ} \mathrm{N}, 19.4^{\circ} \mathrm{W}$, where the circulation veers to the southwest. These limits as well as those of the NAC branches, which were defined from altimetry and the barotropic streamfunction, are indicated in Figures 2-5 and 7. The top-to-bottom integrated transport of the NAC was estimated at $41.8 \pm 3.7 \mathrm{~Sv}$ (Table 3 compiles the transport estimates). The contributions of the northern branch, central (SAF) and southern branches to the NAC transport amounted respectively to $11.0 \pm 3.0 \mathrm{~Sv}, 14.2 \pm 6.4 \mathrm{~Sv}$ and $16.6 \pm 2.0 \mathrm{~Sv}$. The southern NAC branch is composed of two fronts observed between $48.5^{\circ} \mathrm{N}, 21.5^{\circ} \mathrm{W}$ and $46.1^{\circ} \mathrm{N}, 19.4^{\circ} \mathrm{W}$ with top-tobottom transports estimated at 7.4 $\pm 6.6 \mathrm{~Sv}$ and $14.6 \pm 3.7 \mathrm{~Sv}$ respectively, and separated by a southward flow of $4.3 \pm 4.3 \mathrm{~Sv}$ (Figures 4 and Table 3 ).

In isopycnal layers, the NAC transports $27.2 \pm 0.8 \mathrm{~Sv}$ of upper MOC water, $11.9 \pm 1.8$ $\mathrm{Sv}$ of intermediate water and $2.7 \pm 1.4 \mathrm{~Sv}$ of deep water northeastward (Figure 5 ). The vertical distribution of those transports differs from one layer to the other: the circulation in the deep and intermediate layers is more intense for the northern and central branches of the NAC than for the southern branch (Figure 5). Figure 8 shows accordingly that the timeaveraged velocity profile in the southern branch (SAF) is 3.5 (4.5) times more surfaceintensified than in the northern branch, based on the velocity gradient between the surface and $1000 \mathrm{~m}$. This change in baroclinicity is related to changes in isopycnal slopes. Within the southern branch and the SAF, the southeastward deepening of the upper layer isopycnals is the sign of a strongly surface-intensified flow while the flattening of upper layer isopycnals in the northern branch denotes a more barotropic flow (Figure 3). In all three branches, the NAC extends vertically down to the bottom without velocity direction reversal. Similarly synoptic data in the Northwest Corner region (Meinen, 2001) and at the Charlie Gibbs Fracture Zone (e.g.; Schott et al., 1999) showed a NAC extending deeper than the upper MOC layer and reaching the bottom. 


\begin{tabular}{|c|c|c|c|c|c|c|c|}
\hline & & & Name & $\begin{array}{l}\text { Latitude } \\
\left({ }^{\circ} \mathrm{N}\right)\end{array}$ & $\begin{array}{l}\text { Longitude } \\
\left({ }^{\circ} \mathrm{W}\right)\end{array}$ & $\begin{array}{l}\text { Top to } \\
\text { bottom } \\
\text { transport } \\
(\mathrm{Sv})\end{array}$ & $\begin{array}{c}\text { Upper MOC } \\
\text { transport } \\
(\mathrm{Sv})\end{array}$ \\
\hline \multirow{8}{*}{$\begin{array}{l}\text { SPG } \\
-17.0 \pm 3.8 \mathrm{~Sv} \\
\text { top to bottom; } \\
\\
+1.2 \pm 0.9 \mathrm{~Sv} \\
\text { in upper } \mathrm{MOC}\end{array}$} & \multirow{4}{*}{\multicolumn{2}{|c|}{ Greenland }} & WBC & $\begin{array}{l}59.85 \\
59.69\end{array}$ & $\begin{array}{l}42.94 \\
39.60\end{array}$ & $-33.1 \pm 2.6$ & $-3.8 \pm 0.3$ \\
\hline & & & Mid Irminger Sea & $\begin{array}{l}59.69 \\
59.26\end{array}$ & $\begin{array}{l}39.60 \\
35.36\end{array}$ & $+7.7 \pm 2.1$ & $+1.0 \pm 0.3$ \\
\hline & & & IC & $\begin{array}{l}59.26 \\
58.80\end{array}$ & $\begin{array}{l}35.36 \\
31.06\end{array}$ & $+9.5 \pm 3.4$ & $+4.8 \pm 1.1$ \\
\hline & & & EERC & $\begin{array}{l}58.80 \\
57.17\end{array}$ & $\begin{array}{l}31.06 \\
28.00\end{array}$ & $-12.1 \pm 1.1$ & $-4.1 \pm 0.6$ \\
\hline & \multirow{9}{*}{$\begin{array}{l}\text { NAC } \\
+41.8 \pm 3.7 \mathrm{~Sv} \\
\text { top to bottom ; } \\
+27.2 \pm 0.8 \mathrm{~Sv} \\
\text { in upper } \\
\text { MOC }\end{array}$} & \multirow{4}{*}{$\begin{array}{l}\text { Northern } \\
\text { branch } \\
+11.0 \pm 3.0 \mathrm{~Sv} \\
\text { top to bottom; } \\
+3.3 \pm 1.5 \mathrm{~Sv} \\
\text { in upper } \mathrm{MOC}\end{array}$} & Mid Iceland Basin & $\begin{array}{l}57.17 \\
55.90\end{array}$ & $\begin{array}{r}28.00 \\
27.00 \\
\end{array}$ & $+6.3 \pm 3.1$ & $+1.4 \pm 1.1$ \\
\hline & & & Southwestward & $\begin{array}{l}55.90 \\
55.16\end{array}$ & $\begin{array}{r}27.00 \\
26.41\end{array}$ & $-3.1 \pm 1.9$ & $-0.5 \pm 0.8$ \\
\hline & & & Eriador Seamount & $\begin{array}{l}55.16 \\
53.32 \\
\end{array}$ & $\begin{array}{l}26.41 \\
25.00 \\
\end{array}$ & $+10.7 \pm 3.0$ & $+3.4 \pm 1.4$ \\
\hline & & & Southwestward & $\begin{array}{l}53.32 \\
52.59\end{array}$ & $\begin{array}{l}25.00 \\
24.41\end{array}$ & $-2.9 \pm 3.1$ & $-1.0 \pm 1.6$ \\
\hline SAF & & Central branch & SAF & $\begin{array}{l}52.59 \\
50.55\end{array}$ & $\begin{array}{l}24.41 \\
22.83\end{array}$ & $+14.2 \pm 6.4$ & $+8.1 \pm 3.6$ \\
\hline \multirow{5}{*}{$\begin{array}{l}\text { STG } \\
+3.6 \pm 3.5 \mathrm{~Sv} \\
\text { top to bottom; } \\
\\
+7.5 \pm 2.4 \mathrm{~Sv} \\
\text { in upper MOC }\end{array}$} & & \multirow{4}{*}{$\begin{array}{l}\text { Southern } \\
\text { branch } \\
+16.6 \pm 2.0 \mathrm{~Sv} \\
+15.8 \pm 2.2 \mathrm{~Sv} \\
\text { in upper MOC }\end{array}$} & Southwestward & $\begin{array}{l}50.55 \\
49.54 \\
\end{array}$ & $\begin{array}{l}22.83 \\
22.02 \\
\end{array}$ & $-1.1 \pm 3.8$ & $+1.1 \pm 2.6$ \\
\hline & & & First front & $\begin{array}{l}49.54 \\
48.31\end{array}$ & $\begin{array}{l}22.02 \\
21.06 \\
\end{array}$ & $+7.4 \pm 6.6$ & $+7.0 \pm 4.1$ \\
\hline & & & Southwestward & $\begin{array}{l}48.31 \\
47.47\end{array}$ & $\begin{array}{l}21.06 \\
20.41\end{array}$ & $-4.3 \pm 4.3$ & $-3.4 \pm 3.0$ \\
\hline & & & Second front & $\begin{array}{l}47.47 \\
46.14\end{array}$ & $\begin{array}{l}20.41 \\
19.36\end{array}$ & $+14.6 \pm 3.7$ & $+11.1 \pm 2.7$ \\
\hline & 7 & tugal & $\begin{array}{l}\text { West European } \\
\text { Basin }\end{array}$ & $\begin{array}{l}46.14 \\
40.33\end{array}$ & $\begin{array}{c}19.36 \\
9.62\end{array}$ & $-13.0 \pm 2.0$ & $-8.3 \pm 1.3$ \\
\hline
\end{tabular}

Table 3: Transports estimates by regions in $\mathrm{Sv}\left(10^{6} \mathrm{~m}^{3} \mathrm{~s}^{-1}\right)$. The thick horizontal gray lines correspond to the thin vertical gray lines of Figure 2. The subdivisions in the NAC branches are indicated in

Figure 2 as thin vertical dashed gray lines. 


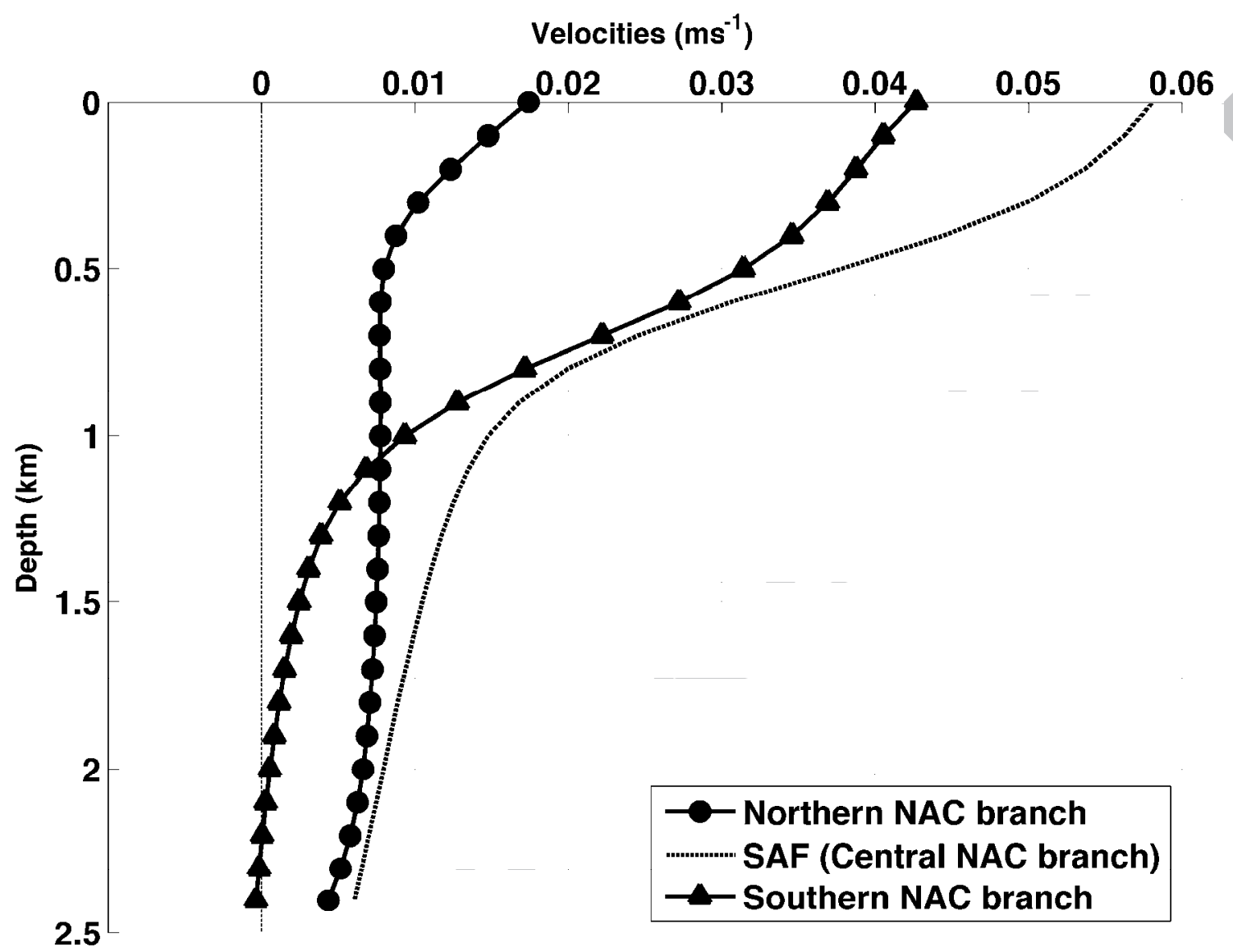

Figure 8: Averaged velocity $\left(\mathrm{m} \mathrm{s}^{-1}\right)$ profiles for the three branches of the NAC.

\subsection{The anticyclonic circulation south of the NAC}

Southeast of the NAC, between $46.1^{\circ} \mathrm{N}, 19.4^{\circ} \mathrm{W}$ and Portugal, the circulation is predominantly southwestward (Figures 2 and 5). The top-to-bottom integrated transport for this part of the section was estimated at $13 \pm 2.0 \mathrm{~Sv}$ towards the subtropics, with a small contribution of the deep layers. We note however, in the Iberian Basin, the northward flow $(0.9 \pm 0.3 \mathrm{~Sv})$ of Lower North East Atlantic Deep Water (LNEADW, Carracedo Segade et al., 2015; the Lower Deep Water of McCartney, 1992). This flow is blocked by bathymetry north 
of the section, upwells and, after strong mixing with the ISOW, returns southwestward at shallower depths (Van Aken, 2000), possibly under the southern branch of the NAC (Figure $5)$.

\subsection{The circulation around the Reykjanes Ridge}

The Reykjanes Ridge is a bathymetric barrier that strongly affects the circulation and water mass distribution in its vicinity (Figures 3 and 4). A general anticyclonic circulation is observed around the Reykjanes Ridge that results from this bathymetric constraint (Figure 1; Bower et al., 2002; Sarafanov et al., 2012; Chafik et al., 2014). On the eastern side of the Reykjanes Ridge, the southwestward circulation consists of two narrow ( $\sim 50 \mathrm{~km})$ flows, centered at $30^{\circ} \mathrm{W}$ and $28^{\circ} \mathrm{W}$, which are separated by a weak northeastward flow confined to the upper layers (Figure 4). The southwestward flow at $30^{\circ} \mathrm{W}$ is a permanent circulation feature with a quasi-barotropic vertical structure (see Figure 4 caption for the definition of a permanent circulation feature). At $28^{\circ} \mathrm{W}$, the southwestward flow is both surface- and bottomintensified and the velocity at intermediate level is low. In between, the weak northward flow mainly results from a very strong anticyclonic eddy sampled in 2002 and damped by the timeaveraging (Figure 2). Following Treguier et al. (2005) who first named the southwestward current on the eastern flank of the Reykjanes Ridge, we refer to the entire region encompassing the two southwestward flows at $28^{\circ} \mathrm{W}$ and $30^{\circ} \mathrm{W}$ as the East Reykjanes Ridge Current (ERRC). The ERRC transport (12.1 $\pm 1.1 \mathrm{~Sv}$ southwestward) was computed as the top-to-bottom integrated transport in the box east of the Reykjanes Ridge crest (Figure 5, Table 3).

Salinity in the upper MOC layer is larger over the eastern flank of the Reykjanes Ridge than at the center of the cyclonic circulation in the Iceland Basin (Figures 3 and 7). Accordingly, the upper part of the ERRC cannot stem solely from the northern branch of the 
NAC that flows through the central Iceland Basin. Keeping in mind the cyclonic circulation in the Iceland Basin, an additional contribution to the ERRC should therefore arise from the SAF that carries water masses with salinity values similar to those observed in the ERRC (Figure 7; Brambilla and Talley, 2008; Lherminier et al., 2010).

On the western side of the Reykjanes Ridge, the top-to-bottom integrated transport of the Irminger Current (IC) was estimated at 9.5 \pm 3.4 Sv northeastward (Figure 5, Table 3). The IC is surface-intensified and more baroclinic than the ERRC (Figure 4). It presents two deep extensions below $\sim 1000 \mathrm{~m}$, a feature similar to that reported by Våge et al. (2011) from a time-averaged velocity field computed for 2001-2005. The transports in the upper MOC and intermediate layers are of similar amplitudes on both sides of the Reykjanes Ridge (4.1 and 4.8 Sv for the upper MOC layer, 3.9 and 4.8 Sv for the intermediate layer, Figure 5). Furthermore, the transported water masses have similar salinities, which are noticeably higher than those of the water masses in the central and western Irminger Sea (Figure 7). Also supported by the altimetry streamfunction (Figure 6), we conclude that there is most likely a direct connection between the IC and the ERRC.

At depth, ISOW is carried southwestward on the eastern flank of the Reykjanes Ridge. ISOW flows into the Irminger Sea through the Charlie-Gibbs Fracture Zone (Saunders, 1994) and through gaps in the ridge north of it, especially the Bight Fracture Zone (Lankhorst and Zenk, 2006). Between the Reykjanes Ridge and $26.5^{\circ} \mathrm{W}$, the flow in the deep layer is composed of 3 permanent southwestward veins (Figure 4) with an associated net transport, including the recirculation, of $3.3 \pm 0.5 \mathrm{~Sv}$ southward. In the Irminger Sea, we found an ISOW transport in the deep layer of $0.8 \pm 0.5 \mathrm{~Sv}$ northward over the western flank of the Reykjanes Ridge and 1.8 $\pm 0.6 \mathrm{~Sv}$ northward in the central Irminger Sea. 


\subsection{The Irminger Gyre and the Western Boundary Current}

In the interior of the Irminger Sea, the circulation is composed of two northward branches (Figure 4), namely the IC along the western flank of the Reykjanes Ridge (see section 3.4) and the eastern rim of the Irminger gyre. The latter is a circulation feature internal to the Irminger Sea, partially connected to the cyclonic circulation in the Labrador Sea (Vage et al., 2011; Lavender et al., 2005). The IC is separated from the northward branch of the Irminger gyre by a weak southward flow. Following Våge et al., (2011), the top-to-bottom transport of the Irminger gyre $(7.7 \pm 2.1 \mathrm{~Sv})$ was estimated as the magnitude of its eastern part (Figure 5, Table 3).

The southward Western Boundary Current (WBC) in the Irminger Sea is composed of the EGIC (East Greenland Irminger Current, $\sigma_{0}<27.8$, see Lherminier et al., (2010) and Daniault et al., 2011a) and the DWBC $\left(\sigma_{0}>27.8\right)$ that carries both ISOW and DSOW. The EGIC is composed of three components - properly the EGC $\left(\sigma_{0}<27.6\right)$, the spill jet (27.6<的 $<27.8)$, (Pickart et al., 2005) and the adjacent IC that usually cannot be separated at $60^{\circ} \mathrm{N}$. Figure 5 shows an inhomogeneous DWBC possibly due to contribution of the cascading north of the OVIDE line (Falina et al., 2012). The WBC total transport was estimated at $33.1 \pm 2.6 \mathrm{~Sv}$, of which $23.4 \pm 1.9 \mathrm{~Sv}$ belongs to the EGIC and $9.7 \pm 0.7 \mathrm{~Sv}$ to the DWBC. The WBC and the core of the IC are permanent features of the circulation (Figure 4).

Between the two cores the circulation is more variable, which is supported by the EKE distribution shown in Figure 2. 


\section{Discussion}

\subsection{Transports of the main currents}

Estimates of the NAC transport available in the literature for the region downstream of the Northwest corner are scattered because of the time and spatial variability affecting the NAC transport at all scales (see Roessler, 2013). To minimize the impact of the variability, we compare our results with time-averaged transport estimates only. West of the MAR, Paillet and Mercier, (1997, see their Figure 8) found $50 \pm 11 \mathrm{~Sv}$ for the top-to-bottom integrated transport between $54^{\circ} \mathrm{N}$ and $46.5^{\circ} \mathrm{N}$ at $35^{\circ} \mathrm{W}$. This estimate, which is based on an inversion of a set of hydrographic observations gathered between 1981 and 1993, is compatible within error bars with the $41.8 \pm 3.7 \mathrm{~Sv}$ found at OVIDE. More recently, analyzing 4 years of data from a CPIES array deployed in August 2006, Roessler et al. (2015) estimated the NAC transport between $52^{\circ} 30^{\prime} \mathrm{N}$ and $47^{\circ} 40^{\prime} \mathrm{N}$, west of the MAR, at $27 \pm 5 \mathrm{~Sv}(0-3400 \mathrm{dbar})$, which is substantially smaller than our estimate. This difference could be related to two factors: 1) Roessler et al. (2015) estimated only the baroclinic component (referenced to 3400 dbar) of the NAC transport; 2) the southern limit of Roessler et al. (2015) array is too north to account for the transport of the southern NAC branch (see Figure 6). For a more accurate comparison, we estimated the NAC transport at OVIDE using limits similar to those of Roessler et al. (2015) (Figure 6). Such a southern limit was defined at OVIDE assuming that the NAC streamlines follow the isolines of surface absolute dynamic topography. The northern limit was set at the center of the Iceland Basin cyclonic circulation. As a result, we found respectively $27 \pm 6 \mathrm{~Sv}$ and $24 \pm 4 \mathrm{~Sv}$ for the total and baroclinic (referenced to 3400 dbar) NAC transports at OVIDE. The baroclinic transport compares reasonably well with Roessler et al. (2015) estimate. We note that the contribution of the neglected velocity at 3400 dbar to the total transport is small $(\sim 3 \mathrm{~Sv})$, which is also the case when considering the NAC transport over its full horizontal extent (41.8 for the total vs. $39.2 \mathrm{~Sv}$ for the baroclinic 
transport). Thus, the difference between the 41.8 Sv NAC transport found at OVIDE and the $27 \mathrm{~Sv}$ found by Roessler et al. (2015) is mainly due to the choice of the geographical limits and the inclusion or not of the southern NAC branch.

We noted earlier that the northern NAC branch is more barotropic than the southern branch (Figure 8). This change in the NAC vertical structure was already evidenced by Sy et al. (1992) who noted that the NAC branch observed at the Charlie-Gibbs Fracture Zone was more barotropic than the branches observed further south on both sides of the MAR. We related the barotropic structure of the mean currents in the northern branch to the flattening of the upper layer isopycnals (Figure 3). As a result, the transport maximum is found at the intermediate level in the northern NAC branch while it is associated with the upper-ocean NACW in the southern branch (Figure 5). Talley et al. (2011) related the difference between the vertical structures of the subtropical and subpolar gyres of the world ocean to the weaker stratification in the subpolar gyres, which could allow deeper penetration of surface signals. The baroclinicity change within the NAC would thus mark the transition from the subtropical to the subpolar gyres.

Between the southern limit of the NAC $\left(46.1^{\circ} \mathrm{N}, 19.4^{\circ} \mathrm{W}\right)$ and Portugal, the top-tobottom transport was estimated at $13 \pm 2.0 \mathrm{~Sv}$ southwestward. It originates from the NAC. This limit is found at the same location as in Paillet and Mercier (1997, their Figure 9). This is likely not a coincidence as the southwestward turn of the flow immediately east of $19.4^{\circ} \mathrm{W}$ is a permanent feature at OVIDE (Figures 4 and 5). It supports our setting of the southern limit of the NAC at this location. Paillet and Mercier (1997) found 16 Sv for the southward recirculation of the NAC in the West European Basin, which compares well with our result.

The ERRC is a permanent circulation element (Figure 4), which confirms Lankhorst and Zenk (2006) results who, based on the analysis of subsurface floats drifting between 1500 
and 2600 dbar underlined the permanent character of the circulation on the eastern flank of the Reykjanes Ridge. The transport of the ERRC, including the ISOW, was estimated at 12.1 $\pm 1.1 \mathrm{~Sv}$. The southwestward flows between the Reykjanes Ridge crest and $27^{\circ} \mathrm{W}$ were missed by previous current measurements (Langseth et al., 1992; Krauss, 1995; Van Aken and De Boer, 1995; Knutsen et al., 2005) with the notable exception of Chafik et al. (2014). Analyzing SADCP velocity measurements in the 0-400 m layer along repeated crossings of the SPG carried out during 1999-2002, Chafik et al. (2014) showed the existence of a 180 $\mathrm{km}$ wide southwestward current on the eastern flank of the Reykjanes Ridge. At the sea surface, our results (Figure 6) are in agreement with Reverdin et al. (2003) and Flatau et al. (2003) who, analyzing surface drifter data, reported a weak southwestward flow on the eastern flank of the Ridge and an intense northeastward IC flowing on the western flank of the Ridge.

The top-to-bottom integrated transport of the IC at OVIDE was estimated at $9.5 \pm 3.4$ Sv (Figure 5), to be compared to the $13 \pm 3$ Sv mean transport reported by Våge et al. (2011) for 1991-2007 and to the $12 \pm 2$ Sv mean transport reported by Sarafanov et al. (2012) for the summers of 2002-2008. Our estimate of the Irminger gyre transport (7.7 $\pm 2.1 \mathrm{~Sv})$ compares favorably to the $6.8 \pm 1.9 \mathrm{~Sv}$ found by Vage et al. (2011). The eastern limb of the Irminger gyre has two branches (Figure 4) in agreement with Våge et al. (2011) mean circulation for 2001-2005. The EGIC and DWBC transports $(23.4 \pm 1.9 \mathrm{~Sv}$ and $9.7 \pm 0.9 \mathrm{~Sv}$, respectively) agree with the $2002-2008$ mean estimates from Sarafanov et al. (2012) at $59.5^{\circ} \mathrm{N}(21.8 \pm 4.3$ $\mathrm{Sv}$ and $10.3 \pm 1.9 \mathrm{~Sv}$, respectively). The EGIC transport between the $200 \mathrm{~m}$ and $2000 \mathrm{~m}$ isobaths was estimated at $19.3 \pm 1.2 \mathrm{~Sv}$, close to the $19.5 \pm 0.3 \mathrm{~Sv}$ reported by Daniault et al. (2011b) for the 1992-2009 time-averaged EGIC transport (19 $\pm 0.3 \mathrm{~Sv}$ if computed over 2002-2012). The DWBC transports at OVIDE and $59.5^{\circ} \mathrm{N}$ are comparable to the $9.0 \pm 1 \mathrm{~Sv}$ found by Bacon and Saunders (2010) for 2005-2006. Finally, defining the combined EGC 
and EGCC as in Sutherland and Pickart (2008), i.e. for salinities less than 34.8, we found a transport $1.5 \pm 0.2 \mathrm{~Sv}$ that compares well with their estimate of $2 \mathrm{~Sv}$, considering that we have missed a little part of the EGCC due to occasional ice cover.

\subsection{Flows over the Reykjanes Ridge}

Lherminier et al. (2010) analyzed the circulation in the SPNA based on a box-model applied to the region limited to the north by the Greenland-Iceland-Scotland Ridge and to the south by the OVIDE section. At the southern boundary, the absolute transports were obtained from OVIDE analyses. At the northern boundary the transports were obtained from literature (see Lherminier et al., 2010 for details). A boundary was set between the Iceland Basin and the Irminger Sea along the Reykjanes Ridge allowing the determination of the transport across the ridge north of $58.5^{\circ} \mathrm{N}$ from volume conservation. This cross-ridge transport was estimated at 9.1 $\pm 2.2 \mathrm{~Sv}$ and $13.8 \pm 2.1 \mathrm{~Sv}$ westward for OVIDE 2002 and 2004, respectively (Lherminier et al., 2010). Adapting this model to their $59.5^{\circ} \mathrm{N}$ line, Sarafanov et al. (2012) also obtained a substantial westward transport of 9.1 Sv over the Reykjanes Ridge north of $59.5^{\circ} \mathrm{N}$. These results are in general agreement with the simulations of the circulation in the SPG by high-resolution models (Treguier et al., 2005) that show large westward transports over the Reykjanes Ridge (10 Sv or more).

We applied Sarafanov et al. (2012) box-model using the same three layers, the OVIDE averaged transports for 2002-2012 at the southern boundary and updated transport values at the Greenland-Scotland Ridge (all values are reported in Figures 9; references are indicated in the captions; note that following Sarafanov et al. (2012) there is no transport of intermediate water at the Iceland-Scotland Ridge). We found a westward volume transport of $11.3 \pm 4.2 \mathrm{~Sv}$ across the Reykjanes Ridge north of $58.5^{\circ} \mathrm{N}$. This cross-ridge transport divides into $6.4 \pm 1.1$ Sv in the upper MOC layer and 4.9 $\pm 3.3 \mathrm{~Sv}$ in the intermediate layer (Figure 9a, 9b). These estimates of the cross-ridge flow are in apparent contradiction with Chafik et al. (2014) who 
suggested that the mean flow (0-400 m) over the Reykjanes Ridge was small north of the 59$60^{\circ} \mathrm{N}$ over $1999-2002$. It is unlikely that the difference comes from the fact that the OVIDE line intersects the Reykjanes Ridge at $58.5^{\circ} \mathrm{N}$ rather than at $59-60^{\circ} \mathrm{N}$, since Sarafanov et al. (2012) found a substantial cross-ridge flow north of $59.5^{\circ} \mathrm{N}$. However, the difference could arise from the vertical structure of the flow that could lead to weak velocities in the upper 400 m. Additional measurements are needed to settle this issue.

\subsection{Circulation schemes}

In this section, we discuss circulation schemes of the northern North Atlantic for the upper, intermediate and deep isopycnal layers (Figures 9a, b, c, Table 2) based on our results complemented by the results of earlier studies.

\subsubsection{Upper MOC layer}

In the upper MOC layer $\left(\sigma_{1}<32.15\right.$, Figure $\left.9 a\right)$, the pathways inferred from altimetry (Figure 6) were found useful to draw a detailed circulation scheme. They highlight the good agreement between our transports and those reported by Sarafanov et al. (2012). The three branches of the NAC previously identified over the MAR were connected to the branches observed at OVIDE. The southern branch linked to the Maxwell Fracture Zone was divided into two parts as suggested by altimetry and in accordance with the observation of two fronts within this branch at OVIDE. The southernmost front feeds the southwestward flow in the West European Basin (8.3 Sv $\pm 1.3 \mathrm{~Sv})$. Altimetry and volume balance imply that the southern NAC branch also feeds the flows over the Rockall Plateau and in the Rockall Trough. The SAF or central NAC branch crosses the MAR at the Faraday Fracture Zone and, as apparent from altimetry (Figure 6), splits downstream into two fronts that eventually converge at OVIDE. North of OVIDE, the SAF joins the part of the southern NAC branch that flows over the Rockall Plateau. At $59.5^{\circ} \mathrm{N}$, the transport over the Rockall Plateau (8.5 Sv) 
is larger than the transport through the Rockall Trough (1.9 Sv). The latter compares well with the 23-year average transport across the Ellett hydrographic line $\left(56-57.7^{\circ} \mathrm{N}\right)$, in the northern Rockall Trough, which was estimated at $2.5 \pm 1.6 \mathrm{~Sv}$ in the upper $500 \mathrm{dbar}$ by Holliday et al. (2000). The branches over the Rockall Plateau and through the Rockall Through contribute to the flows across the Iceland-Scotland Ridge and possibly around Iceland.

The cyclonic circulation in the Iceland Basin stems from the SAF and the northern NAC branch (Figure 9a). The latter is relatively weak in the upper MOC layer because the northern NAC branch flows parallel to the OVIDE section before veering northeastward after the Maury Channel, a feature that was already observed by Pollard et al. (2004). The water carried by this cyclonic circulation feeds the ERRC on its eastern side. On its western side, water leaves the ERRC to feed the cross-Ridge transport and the IC. The transport across the Reykjanes Ridge was estimated at $6.4 \pm 1.1 \mathrm{~Sv}$ north of OVIDE. Considering that the ERRC south of OVIDE continues into the IC, we estimated that the cross-ridge transport south of OVIDE was $\sim 4-5 \mathrm{~Sv}$. Our results suggest that the more direct route from the northern NAC branch to the IC (dashed line on Figure 9a, southwest of OVIDE) has a small transport in average.

In the upper MOC layer, the transport of the IC and the intensity of the Irminger gyre were estimated at $4.8 \pm 1.1 \mathrm{~Sv}$ and $1.0 \pm 0.3 \mathrm{~Sv}$ respectively. In the Irminger Sea, north of OVIDE, the strong heat loss in fall and winter leads to intense convective mixing (Pickart et al., 2003; Brambilla and Talley, 2008; Piron et al., 2016) and to transformation of upper MOC water into denser lower MOC water at a rate of 9.6 $\pm 1.2 \mathrm{~Sv}$ (Figure 9a). This downwelling results from the volume balance of the box model presented in section 4.2 and its strength is similar to that reported by Sarafanov et al. (2012) $(10.2 \pm 1.7 \mathrm{~Sv})$. As sketched in Figure 9, the upper MOC layer $\left(\sigma_{1}<32.15\right)$ becomes very thin $(<200 \mathrm{~m}$ thick) off Cape Farewell (see 
Figure 3) in response to this water mass conversion and nearly vanishes in the Labrador Sea

(Desbruyères, 2013) except for the fresh Labrador Current over the shelf.

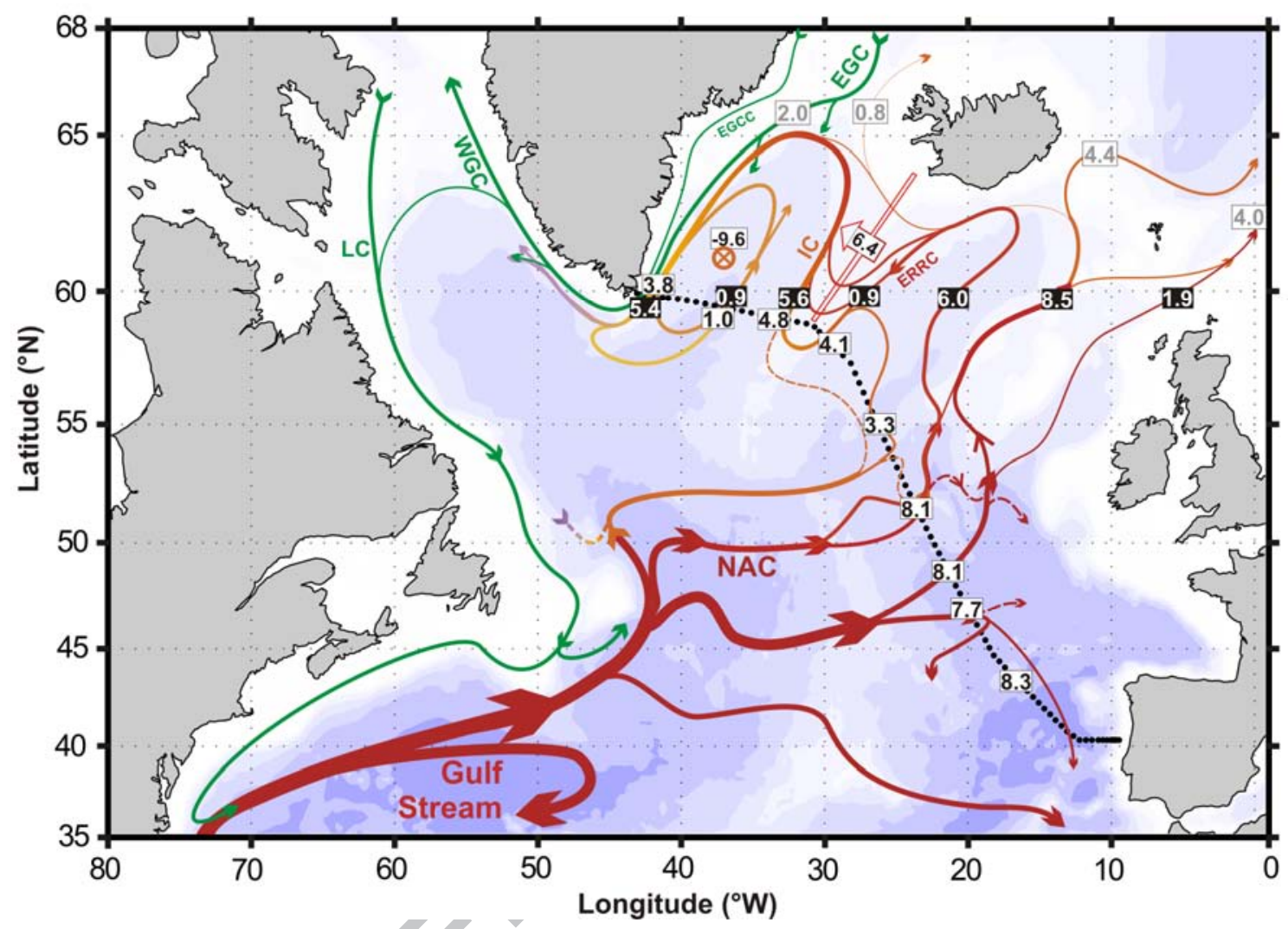

Figure 9a: Circulation scheme for the isopycnal layer corresponding to the upper limb of the MOC ( $\sigma 1$ $<32.15$ as in Mercier et al., 2015). Main currents are indicated: East Greenland Current (EGC), East Greenland Coastal Current (EGCC), West Greenland Current (WGC), Labrador Current (LC), North Atlantic Current (NAC), East Reykjanes Ridge Current (ERRC) and Irminger Current (IC). Black numbers on white background are from Figure 5 or Table 3 and from the volume budget derived in $\S$ 4.2. White numbers on black background are from (Sarafanov et al., 2012), gray numbers are from (Rossby and Flagg, 2012) for Iceland-Scotland Ridge and (Østerhus et al., 2008) and (Sutherland and Pickart, 2008) for the Denmark Strait. The circle with a cross inside denotes a diapycnal downwelling. The circulation scheme was drawn from these observations using the absolute dynamical altimetry averaged over 2002-2012 summer months (Figure 7), Dickson et al. (2008), Brambilla and Talley (2008), Sutherland and Pickart (2008), Lherminier et al. (2010), Sarafanov et al. (2012), Rossby (1996), Holliday et al. (2009) and Våge et al. (2011) as additional sources of information on circulation pathways.

\subsubsection{Intermediate layer}

The OVIDE data provide a new quantification of the transports of intermediate water in the eastern North Atlantic (Figure 9b). The NAC transports $11.9 \pm 1.8 \mathrm{~Sv}$ of intermediate 
water eastward across OVIDE (Figure 5), mainly within the SAF and the northern NAC branch with only $1.8 \pm 0.9 \mathrm{~Sv}$ associated with the southern branch, in accordance with the surface-intensified nature of the latter. The anticyclonic circulation of intermediate water in the West European Basin was quantified as the transport of the southwestward flow found northwest of the Azores-Biscay Rise $(4.5 \pm 0.4 \mathrm{~Sv})$. This result is in general agreement with Paillet et al. (1998) who suggested that the southwestward circulation of Labrador Sea Water (LSW) stems from a cross-MAR flow north of $47.5^{\circ} \mathrm{N}$. According to these authors the southwestward flow of LSW is thought to cross the MAR through the Oceanographer Fracture Zone towards the western basin and to join the DWBC at mid-latitudes.

The intermediate water circulates in the Rockall Trough, around the Rockall Plateau and cyclonically in the Iceland Basin (Bower et al., 2002; Ollitrault and Colin de Verdière, 2014) (Figure 9b). From the northern limit of the NAC to Portugal, the net transport of intermediate water across OVIDE is 7.4 Sv northward (Figures 5 and 9b). This includes $4.5 \mathrm{~Sv}$ of intermediate water circulating towards the subtropics in the southern part of the section. The ERRC transports 4.8 Sv of intermediate water southwestward. The net northward transport of $1 \mathrm{~Sv}$ of intermediate water found east of $17^{\circ} \mathrm{W}$ at $59.5^{\circ} \mathrm{N}$ by Sarafanov et al. (2012) is likely fed by the net flow through the Rockall Trough that was evidenced by Ollitrault and Colin de Verdière (2014) at $1000 \mathrm{~m}$. In the Iceland Basin, the circulation consists of two main pathways: a northward branch that connects to the $5.3 \mathrm{~Sv}$ transport across $59.5^{\circ} \mathrm{N}$ and a westward branch of $3.4 \mathrm{~Sv}$ (Figure 9b). The latter transport was inferred from the $2.3 \mathrm{~Sv}$ upwelling of deep water resulting from the volume balance of the deep layer (Figure 9c) and the volume balance between the net isopycnal (horizontal) transports across the OVIDE and $59.5^{\circ} \mathrm{N}$ sections (i.e. $5.7+4.4+1.8-4.5+2.3-\mathrm{X}=1+5.3$ gives $\mathrm{X}=3.4 \mathrm{~Sv}$, Figures $9 \mathrm{~b}$ ).

The net intermediate transport of $2.6 \mathrm{~Sv}$ northward across OVIDE, east of the Reykjanes Ridge crest, adds to the $2.3 \pm 1.5 \mathrm{~Sv}$ upwelling in the eastern basin to feed the flow 
over the Reykjanes Ridge $(4.9 \pm 3.3 \mathrm{~Sv})$ into the Irminger Sea. Sarafanov et al. (2012) found 1.2 Sv for the cross-Ridge transport of intermediate water north of $59.5^{\circ} \mathrm{N}$. Accordingly, most of $4.9 \mathrm{~Sv}$ flow of intermediate water across the Ridge has to occur between OVIDE at $58.5^{\circ} \mathrm{N}$ and $59.5^{\circ} \mathrm{N}$. This is possibly related to the southward deepening of the Reykjanes Ridge towards the OVIDE section.

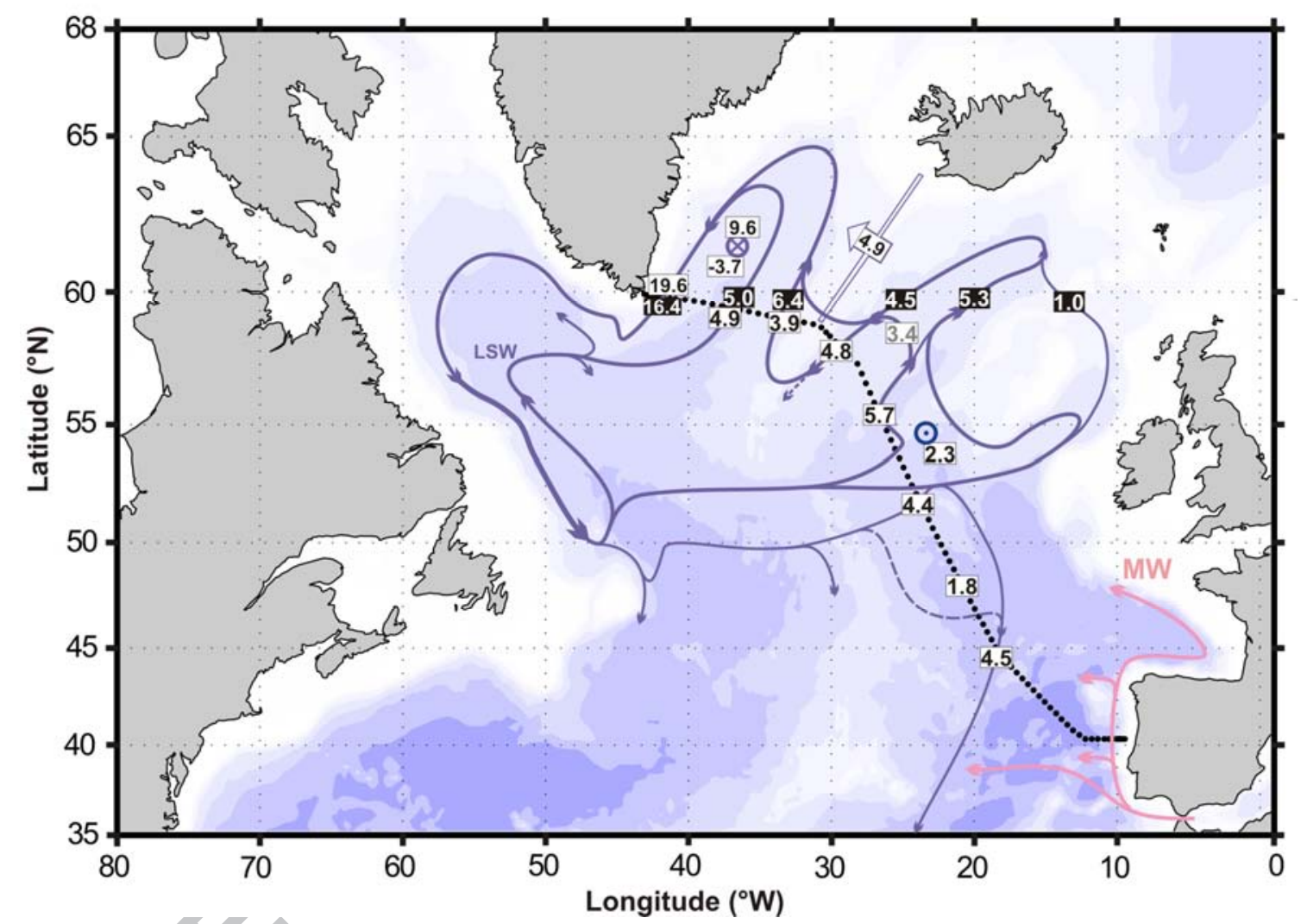

Figure 9b: Circulation scheme for the intermediate layer delimited by the isopycnals $\sigma 1=32.15$ and $\sigma 0=27.80$ or $\sigma 2<36.94$ (see Figure 4). Black numbers on white background are from Figure 5 and from a volume budget derived in $\S 4.2$. White numbers on black background come from (Sarafanov et al., 2012). The circle with a cross inside denotes a diapycnal downwelling; the circle with a dot inside denotes a diapycnal upwelling. The circulation scheme was drawn from these observations and using Ollitrault and Colin de Verdière (2014), Dengler et al. (2006), Cuny et al. (2002), New and SmytheWright (2001), Holliday et al. (2009), Paillet et al. (1998) and Lavender et al. (2005) as additional sources of information on the circulation pathways.

The transport of intermediate water increases during the cyclonic circulation around the Irminger Sea (Figure 9b). This increase is associated with the inflow of intermediate water from the Iceland Basin over the Reykjanes Ridge and with the downward volume flux from 
the upper layer (possibly including shelf water cascading in the northern Irminger Sea as reported by Pickart et al., 2005 and Falina et al., 2012). The joint northward transport of intermediate water across OVIDE by the IC $(3.9 \pm 1.8 \mathrm{~Sv})$ and the eastern limb of the Irminger gyre $(4.9 \pm 1.4 \mathrm{~Sv})$ is $8.8 \pm 1.7 \mathrm{~Sv}$ northward, which is less than the $11.4 \pm 1.7 \mathrm{~Sv}$ found at $59.5^{\circ} \mathrm{N}$ by Sarafanov et al. (2012) (Figure 9b). This difference comes from a smaller IC transport at $\mathrm{OVIDE}\left(58.5^{\circ} \mathrm{N}, 3.9 \pm 1.8 \mathrm{~Sv}\right)$ than at $59.5^{\circ} \mathrm{N}(6.4 \pm 1.6 \mathrm{~Sv})$. The transport of intermediate water by the EGIC was estimated at $19.6 \pm 1.6 \mathrm{~Sv}$ southward $(16.4 \pm 3.9 \mathrm{~Sv}$ in Sarafanov et al., 2012). In terms of the net diapycnal volume transports between the layers inferred from the volume budgets, this intermediate layer in the Irminger Sea gains 9.6 Sv from the upper layer and loses $3.7 \mathrm{~Sv}$ toward the deep layer.

\subsubsection{Deep layer}

In the deepest southeastern part of the OVIDE section, we observed $0.9 \mathrm{~Sv}$ of northward flowing LNEADW (Figures 5 and 9c). About $1 \mathrm{~Sv}$ of NEADW is found to recirculate southward at $50^{\circ} \mathrm{N}, 22^{\circ} \mathrm{W}$, following the $4000 \mathrm{~m}$ isobath (Figures $9 \mathrm{c}$ and 5). The $1.1 \mathrm{~Sv}$ found at $45^{\circ} \mathrm{N}, 19^{\circ} \mathrm{W}$ (Figure 9c) are mainly localized in a deep extension of the LSW flow (Figure $5)$.

The ISOW transport across the Iceland-Scotland Ridge amounts to $3 \mathrm{~Sv}$ (Østerhus et al., 2008). Some entrainment occurs south of the sills (Dickson et al., 2002), but our integral method prevents from giving an exact number. We found $3.2 \pm 0.4 \mathrm{~Sv}$ for the southward transport of ISOW along the eastern flank of the Reykjanes Ridge (Figure 9c). This estimate compares favorably with other estimates south of Iceland: Saunders (1996) found $3.2 \pm 0.5 \mathrm{~Sv}$ from a current meter array; Kanzow and Zenk (2014) found 3.8 $\pm 0.6 \mathrm{~Sv}$ from a combined moored current meter/hydrography array; Xu et al. (2010) found 3.3 Sv in an eddy-resolving numerical simulation of the ocean circulation. Transports of ISOW across OVIDE in the 
Iceland Basin were observed in three different current veins suggesting three different pathways for ISOW from the Iceland-Scotland Ridge, which is supported by Xu et al. (2010) simulations. The latter were used to draw the fate of these ISOW pathways: the westernmost branch crosses the Reykjanes Ridge through the Bight Fracture Zone; the middle branch flows mainly through the Charlie-Gibbs Fracture Zone; the easternmost branch flows southward into the Maury Channel.

In the Irminger Sea, we found the main northward pathway for ISOW in the interior part of the basin (Figure 9c). We suggest that this interior ISOW flow comes from the CharlieGibbs Fracture Zone while the northward flow of ISOW (0.8 Sv) found over the western flank of the Reykjanes Ridge is connected to the flow across the Bight Fracture Zone. The DWBC shows a southward transport of $9.7 \pm 0.9 \mathrm{~Sv}$ of water denser than $\sigma_{0}=27.8$ (Figure $9 \mathrm{c}$ ). It cumulates the contributions of the northward transport of ISOW entering the Irminger Basin (2.6 Sv), the Denmark Strait overflow (3.4 Sv, Jochumsen et al., 2012) and the downward transport from the intermediate to the deep layer $(3.7 \pm 1.3 \mathrm{~Sv})$. The latter likely includes LSW and some contribution from the cascading of east Greenland shelf water down to the DWBC, which could occasionally reach $2 \mathrm{~Sv}$ (Falina et al., 2012). Our estimate $(9.7 \pm 0.9 \mathrm{~Sv})$ is in line with the most recent DWBC transports reported by Sarafanov et Al. (2012) (10.3 \pm 1.9 Sv), Våge et Al. (2011) (9.6 $\pm 1.4 \mathrm{~Sv})$ and Bacon and Saunders (2010) (9Sv).

Finally, we observed a northeastward transport of deep water (3.7 Sv) in the deep extension of the NAC (Figure 9c), similar in amplitude to that of the ISOW flow entering the basin at the Iceland-Scotland sills. Along with the LNEADW, this northeastward flow is likely a source for the large upwelling of deep water $(2.3 \mathrm{~Sv})$ found in the West European Basin. The upwelling might be even larger considering that this net diapycnal flux includes the entrainment of water from the upper and intermediate layers into the ISOW overflows $(0.3$ Sv according to Kanzow and Zenk, 2014). 


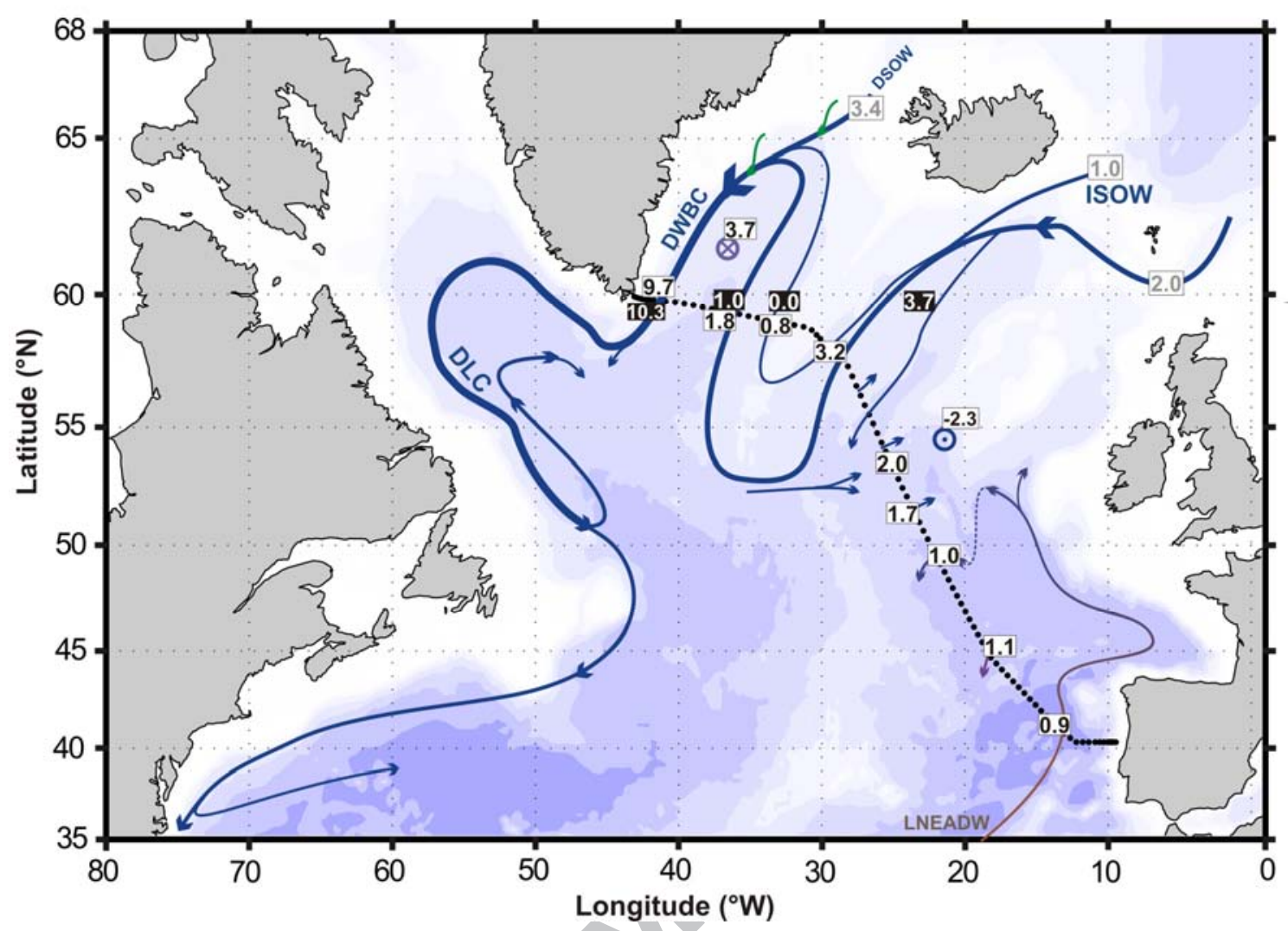

Figure 9c: Circulation scheme for the deep layer delimited by the isopycnal $\sigma 0=27.80$ except in the east where we used $\sigma 2=36.94$ (see Figure 4). Main currents are indicated: Deep Labrador Current (DLC), Deep Western Boundary Current (DWBC). Overflow water masses are indicated: Denmark Strait Overflow Water (DSOW), Iceland-Scotland Overflow Water (ISOW). Black numbers on white background are from Figure 5 and from a volume budget derived in $\S 4.2$. White numbers on black background are from Sarafanov et al. (2012), gray numbers at the Greenland Scotland Ridge are from Dickson et al. (2008). The circle with a cross inside denotes a diapycnal downwelling; the circle with a dot inside denotes a diapycnal upwelling. The circulation scheme was drawn from these observations using Xu et al. (2010) and Saunders (1994) as additional sources of information on circulation pathways.

\section{Conclusion}

We quantified the decadal mean circulation across the Greenland-Portugal OVIDE section by averaging the absolute velocities derived by inversions of the hydrographic and SADCP data gathered every other summer between 2002 and 2012. The mean circulation obtained by averaging 6 surveys reveals the main circulation features that are blurred by the mesoscale variability in synoptic circulation estimates (see e. g. Figure 2). The obtained mean 
velocities are in good quantitative agreement with the mean velocities derived from the LADCP data and, at the surface, from the altimetry data. We found several permanent features mainly in the cores of the WBC, the IC, the ERRC, also in a flow at the southern limit of the NAC (Figures 4 and 5). We presented and discussed our quantification of the decadal mean transport of the NAC in the eastern North Atlantic and detailed its partition into three different branches (Figure 5, Table 3). We elucidated the fate of the NAC branches north of the OVIDE section by connecting them to observations at $59.5^{\circ} \mathrm{N}$ and at the Greenland-Scotland Ridge (Figure 9). The top-to-bottom NAC transport was estimated at 42 Sv northwestward (see Table 3 for errors). We noted that this estimate is larger than the $27 \mathrm{~Sv}$ found west of the MAR by Roessler et al. (2015) whose observations did not include the southernmost part of the NAC southern branch. We argued that the NAC feeds i) the ERRC, which transport was estimated at $9 \mathrm{~Sv}$ (without the contribution of the ISOW); ii) the flow over the Reykjanes Ridge (11 Sv); iii) the flow across the Greenland-Scotland Ridge (9 Sv from the literature); iv) the southwestward circulation in the west European Basin (13 Sv).

We built quantitative circulation schemes for the upper MOC, intermediate and deep isopycnal layers based on our results and those reported for the 2000s by Sarafanov et al. (2012) at $59.5^{\circ} \mathrm{N}$, other time-averaged estimates from the literature, and altimetry. The remarkably good quantitative agreement between all estimates led us to draw pathways with a high level of confidence. In the upper MOC layer, the main features follow the routes of the top-to-bottom integrated NAC. Notably, we noted that the flow through the Iceland-Scotland Ridge was mainly fed by the northern part of the southern branch. We also observed that the intermediate water enters the eastern basin mostly through the northern and central branches of the NAC. About half of it flows anticyclonically in the West European Basin and join the recirculating component of the southern NAC branch. In the deep water layer, we identified three southward veins of ISOW in the Iceland Basin. In the Irminger Sea, we identified two 
veins of ISOW that seem to connect to the two westernmost branches in the Iceland Basin through the Bight and Charlie-Gibbs Fracture Zones. Overall, the deep circulation in the West European Basin remains poorly known and would deserve more dedicated measurements, possibly through deployment of deep Lagrangian floats. Finally, by quantifying the diapycnal flux between the upper (intermediate) MOC layer and the intermediate (deep) layer at $10 \mathrm{Sy}$ (4 Sv) in the Irminger Sea, this study confirms that the Irminger Sea plays a major role in setting the properties of the water masses of the MOC lower limb.

\section{Acknowledgements}

This research was supported by CNRS, by Ifremer, the French national program LEFE coordinated by INSU, the EU FP7 project CARBOCHANGE "Changes in carbon uptake and emissions by oceans in a changing climate", which received funding from the European Commission Seventh Framework Programme under grant agreement no. 264879. This research is a contribution to the OVIDE project, OSNAP and CLIVAR. It benefited of support from the French research infrastructure TGIR flotte (RV Thalassa). Herlé Mercier was supported by CNRS. Artem Sarafanov and Anastasia Falina were supported by the RSF grant 14-50-00095 and the RFBR grants 15-05-03782, 15-05-02250. A.F. Rios and F.F. Pérez were supported by the Consejo Superior de Investigaciones Científicas (CSIC) and the Spanish Ministry of Economy and Competitiveness (BES-2011-045614) through the CATARINA project (CTM2010-17141) and BOCATS (CTM2013-41048-P) projects both cofunded by the Fondo Europeo de Desarrollo Regional (FEDER). 


\section{References}

Bacon, S., Saunders, P.M., 2010. The Deep Western Boundary Current at Cape Farewell: Results from a Moored Current Meter Array. Journal of Physical Oceanography 40, 815-829. doi:10.1175/2009JPO4091.1.

Bersch, M., 2002. North Atlantic Oscillation-induced changes of the upper layer circulation in the northern North Atlantic Ocean. Journal of Geophysical Research 107 (C10), 3156. doi:10.1029/2001JC000901.

Bower, A.S., Le Cann, B., Rossby, T., Zenk, W., Gould, J., Speer, K., Richardson, P.L., Prater, M.D., Zhang, H.M., 2002. Directly measured mid-depth circulation in the northeastern North Atlantic Ocean. Nature 419, 603-607. doi:10.1038/nature01078.

Bower, A.S., von Appen, W.J., 2008. Interannual variability in the pathways of the North Atlantic current over the Mid-Atlantic Ridge and the impact of topography. Journal of Physical Oceanography 38, 104-120. doi:10.1175/2007JPO3686.1.

Brambilla, E., Talley, L.D., 2008. Subpolar Mode Water in the northeastern Atlantic: 1. Averaged properties and mean circulation. Journal of Geophysical Research 113, C04025. doi:10.1029/2006JC004062.

Branellec, P., Lherminier, P., 2009. Campagne OVIDE 2006 : Rapport de données CTD-O2. (No. DRO/DOPS/LPO/09-03). Laboratoire d'Océanographie Physique et Spatiale.

Carracedo Segade, L.I., Gilcoto, M., Mercier, H., Pérez, F.F., 2015. Quasi-synoptic transport, budgets and water mass transformation in the Azores-Gibraltar Strait region during summer 2009. Progress in Oceanography 130, 47-64. doi:10.1016/j.pocean.2014.09.006.

Chafik, L., Rossby, T., Schrum, C., 2014. On the spatial structure and temporal variability of poleward transport between Scotland and Greenland. Journal of Geophysical Research Oceans 119, 824-841. doi:10.1002/2013JC009287.

Cuny, J., Rhines, P.B., Niiler, P.P., Bacon, S., 2002. Labrador Sea Boundary Currents and the Fate of the Irminger Sea Water. Journal of Physical Oceanography 32, 626-647.

doi:10.1175/1520-0485(2002)032<0627:LSBCAT>2.0.CO;2

Daniault, N., Lherminier, P., Mercier, H., 2011a. Circulation and Transport at the Southeast Tip of Greenland. Journal of Physical Oceanography 41, 437-457. doi:10.1175/2010JPO4428.1.

Daniault, N., Mercier, H., Lherminier, P., 2011b. The 1992-2009 transport variability of the East Greenland-Irminger Current at $60^{\circ} \mathrm{N}$. Geophysical Research Letters 38, L07601. doi:10.1029/2011GL046863. 
de Boisséson, E., Thierry, V., Mercier, H., Caniaux, G., 2010. Mixed layer heat budget in the Iceland Basin from Argo. Journal of Geophysical Research 115, C10055.

doi:10.1029/2010JC006283.

de Jong, M.F., van Aken, H.M., Våge, K., Pickart, R.S., 2012. Convective mixing in the central Irminger Sea: 2002-2010. Deep-Sea Research I 63, 36-51.

doi:10.1016/j.dsr.2012.01.003.

Dengler, M., Fischer, J., Schott, F.A., Zantopp, R., 2006. Deep Labrador Current and its variability in 1996-2005. Geophysical Research Letters 33, L21S06. doi:10.1029/2006GL026702.

Desbruyères Damien (2013). The Meridional Overturning Circulation variability and heat content changes in the North Atlantic subpolar gyre. PhD Thesis, Universite de Bretagne Occidentale. http://archimer.ifremer.fr/doc/00119/23064/.

Dickson, R.R., Yashayaev, I., Meincke, J., Turrell, W., Dyes, S., Holfort, J., 2002. Rapid freshening of the deep North Atlantic over the past four decades. Nature, 416, 832-837. doi:10.1038/416832a.

Dickson, R.R., Meincke, J., Rhines, P. (Eds.), 2008. Arctic-Subarctic Ocean Fluxes. Springer Netherlands, Dordrecht. ISBN 978-1-4020-6774-7.

Dutkiewicz, S., Rothstein, L., Rossby, T., 2001. Pathways of cross-frontal exchange in the North Atlantic Current. Journal of Geophysical Research 106, (C11), 26917-26928. doi:10.1029/1999JC000089.

Egbert, G.D., Erofeeva, S.Y., 2002. Efficient Inverse Modeling of Barotropic Ocean Tides. J. Atmospheric Ocean. Technol. 19,183-204. doi:10.1175/1520-

0426(2002)019<0183:EIMOBO>2.0.CO;2

Falina, A., Sarafanov, A., Mercier, H., Lherminier, P., Sokov, A., Daniault, N., 2012. On the Cascading of Dense Shelf Waters in the Irminger Sea. Journal of Physical Oceanography 42, 2254-2267. doi:10.1175/JPO-D-12-012.1.

Flatau, M.K., Talley, L., Niiler, P.P., 2003. The North Atlantic Oscillation, surface current velocities, and SST changes in the subpolar North Atlantic. Journal of Climate 16, 23552369. doi: $10.1175 / 2787.1$

García-Ibáñez, M.I., Pardo, P.C., Carracedo, L.I., Mercier, H., Lherminier, P., Ríos, A.F., Pérez, F.F., 2015. Structure, transports and transformations of the water masses in the Atlantic Subpolar Gyre. Progress in Oceanography 135, 18-36. doi:10.1016/j.pocean.2015.03.009.

Gourcuff, C., Lherminier, P., Mercier, H., Le Traon, P.Y., 2011. Altimetry Combined with Hydrography for Ocean Transport Estimation. Journal of Atmospheric Oceanographic Technology 28, 1324-1337. doi:10.1175/2011JTECHO818.1. 
Hakkinen, S., Rhines, P.B., 2009. Shifting surface currents in the northern North Atlantic Ocean. Journal of Geophysical Research 114, C04005. doi:10.1029/2008JC004883.

Harvey, J., Arhan, M., 1988. The Water Masses of the Central North Atlantic in 1983-84. Journal of Physical Oceanography 18, 1855-1875. doi:10.1175/15200485(1988)018<1855:TWMOTC>2.0.CO;2.

Holliday, N.P., Bacon, S., Allen, J., McDonagh, E.L., 2009. Circulation and Transport in the Western Boundary Currents at Cape Farewell, Greenland. Journal of Physical Oceanography 39, 1854-1870. doi:10.1175/2009JPO4160.1.

Holliday, N.P., Pollard, R.T., Read, J.F., Leach, H., 2000. Water mass properties and fluxes in the Rockall Trough, 1975-1998. Deep Sea Resarch I 47, 1303-1332. doi:10.1016/S09670637(99)00109-0.

Jochumsen, K., Quadfasel, D., Valdimarsson, H., Jonsson, S., 2012. Variability of the Denmark Strait overflow: Moored time series from 1996-2011. Journal of Geophysical Research-Oceans 117. doi:10.1029/2012JC008244.

Kanzow, T., Zenk, W., 2014. Structure and transport of the Iceland Scotland Overflow plume along the Reykjanes Ridge in the Iceland Basin. Deep Sea Research I 86, 82-93. doi:10.1016/j.dsr.2013.11.003.

Khatiwala, S., Tanhua, T., Mikaloff Fletcher, S., Gerber, M., Doney, S.C., Graven, H.D., Gruber, N., McKinley, G.A., Murata, A., Ríos, A.F., Sabine, C.L., 2013. Global ocean storage of anthropogenic carbon. Biogeosciences 10, 2169-2191. doi:10.5194/bg-10-2169-2013.

Knutsen, O., Svendsen, H., Østerhus, S., Rossby, T., Hansen, B., 2005. Direct measurements of the mean flow and eddy kinetic energy structure of the upper ocean circulation in the NE Atlantic. Geophysical Research Letters 32, L14604. doi:10.1029/2005GL023615.

Krauss, W., 1995. Current and mixing in the Irminger Sea and in the Iceland Basin. Journal of Geophysical Research 100, 10851 -10871. doi: 10.1029/95JC00423.

Langseth, M.G., Becker, K., Von Herzen, R.P., Schultheiss, P., 1992. Heat and fluid flux through sediment on the western flank of the Mid-Atlantic Ridge: A hydrogeological study of North Pond. Geophysical Research Letters 19, 517-520. doi:10.1029/92GL00079.

Lankhorst, M., Zenk, W., 2006. Lagrangian observations of the middepth and deep velocity fields of the northeastern Atlantic Ocean. Journal of Physical Oceanography 36, 43-63. doi:10.1175/JPO2869.1.

Lavender, K., Owens, W.B., Davis, R.E., 2005. The mid-depth circulation of the subpolar North Atlantic Ocean as measured by subsurface floats. Deep-Sea Research I 52, 767-785. doi:10.1016/j.dsr.2004.12.007. 
Lherminier, P., Mercier, H., Gourcuff, C., Alvarez, M., Bacon, S., Kermabon, C., 2007. Transports across the 2002 Greenland-Portugal Ovide section and comparison with 1997. Journal of Geophysical Research 112, C07003. doi:10.1029/2006JC003716.

Lherminier, P., Mercier, H., Huck, T., Gourcuff, C., Perez, F.F., Morin, P., Sarafanov, A., Falina, A., 2010. The Atlantic Meridional Overturning Circulation and the subpolar gyre observed at the A25-OVIDE section in June 2002 and 2004. Deep-Sea Res. I, 57, 1374-1391. doi:10.1016/j.dsr.2010.07.009.

McCartney, M.S., Talley, L., 1982. The Subpolar Mode Water of the North Atlantic Ocean. Journal of Physical Oceanography 12, 1169-1188. doi: 10.1175/1520-0485(1982)012<1169: TSMWOT>2.0.CO;2.

Meinen, C.S., 2001. Structure of the North Atlantic current in stream-coordinates and the circulation in the Newfoundland basin. Deep Sea Research I 48, 1553-1580. doi:10.1016/S0967-0637(00)00103-5.

Mercier, H., Lherminier, P., Sarafanov, A., Gaillard, F., Daniault, N., Desbruyères, D., Falina, A., Ferron, B., Gourcuff, C., Huck, T., Thierry, V., 2015. Variability of the meridional overturning circulation at the Greenland-Portugal OVIDE section from 1993 to 2010. Progress in Oceanography 132, 250-261. doi:10.1016/j.pocean.2013.11.001.

New, A., Smythe-Wright, D., 2001. Aspects of the circulation in the Rockall Trough. Continental Shelf Research 21, 777-810. doi:10.1016/S0278-4343(00)00113-8.

Ollitrault, M., Colin de Verdière, A., 2014. The Ocean General Circulation near 1000-m Depth. Journal of Physical Oceanography 44, 384-409. doi:10.1175/JPO-D-13-030.1.

Orvik, K.A., Niiler, P.P., 2002. Major pathways of Atlantic water in the northern North Atlantic and Nordic Seas toward Arctic. Geophysical Research Letters 29 (19), 1896. doi:10.1029/2002GL015002.

Østerhus, S., Sherwin, T., Quadfasel, D., Hansen, B., 2008. The overflow transport east of Iceland, in: Dickson, R.R., Meincke, J., Rhines, P.B. (Eds.), Arctic-Subarctic Ocean Fluxes. Dordrecht, pp. 427-442. doi: 10.1007/978-1-4020-6774-7_19.

Paillet, J., Arhan, M., McCartney, M.S., 1998. Spreading of Labrador Sea Water in the eastern North Atlantic. Journal of Geophysical Research 103, 10223. doi:10.1029/98JC00262.

Paillet, J., Mercier, H., 1997. An inverse model of the eastern North Atlantic general circulation and thermocline ventilation. Deep-Sea Research I 44, 1293-1328. doi:10.1016/S0967-0637(97)00019-8.

Pérez, F.F., Mercier, H., Vàzquez-Rodríguez, M., Lherminier, P., Velo, A., Pardo, P.C., Roson, G., Ríos, A.F., 2013. Atlantic Ocean CO2 uptake reduced by weakening of the meridional overturning circulation. Nature Geoscience 6, 146-152. doi:10.1038/NGEO1680. 
Pérez, F.F., Vàzquez-Rodríguez, M., Mercier, H., Velo, A., Lherminier, P., Ríos, A.F., 2010. Trends of anthropogenic CO2 storage in North Atlantic water masses. Biogeosciences 7 , 1789-1807. doi:10.5194/bg-7-1789-2010.

Pickart, R.S., Spall, M.A., Ribergaard, M.H., Moore, G.W., Milliff, R.F., 2003. Deep convection in the Irminger Sea forced by the Greenland tip jet. Nature 424, 182-156. doi: 10.1038/nature01729.

Pickart, R.S., Torres, D.J., Fratantoni, P.S., 2005. The East Greenland Spill Jet. Journal of Physical Oceanography 35, 1037-1053. doi:10.1175/JPO2734.1.

Piron, A., Thierry, V., Mercier, H., Caniaux, G., 2016. Argo float observations of basin-scale deep convection in the Irminger sea during winter 2011-2012. Deep Sea Research I 109, 7690. doi:10.1016/j.dsr.2015.12.012.

Pollard, R.T., Read, J.F., Holliday, N.P., 2004. Water masses and circulation pathways through the Iceland Basin during Vivaldi 1996. Journal of Geophysical Research 109, C04004. doi:10.1029/2003JC002067.

Rattan, S., Myers, P.G., Treguier, A.-M., Theetten, S., Biastoch, A., Böning, C., 2010. Towards an understanding of Labrador Sea salinity drift in eddy-permitting simulations. Ocean Modelling 35, 77-88. doi:10.1016/j.ocemod.2010.06.007.

Reverdin, G., Niiler, P.P., Valdimarsson, H., 2003. North Atlantic Ocean surface currents. Journal of Geophysical Research 108 (C1), 3002. doi:10.1029/2001JC001020.

Rhein, M., Kieke, D., Huettl-Kabus, S., Roessler, A., Mertens, C., Meissner, R., Klein, B., Boening, C.W., Yashayaev, I., 2011. Deep water formation, the subpolar gyre, and the meridional overturning circulation in the subpolar North Atlantic. Deep-Sea Res. Part IiTop. Stud. Oceanogr. 58, 1819-1832. doi:10.1016/j.dsr2.2010.10.061

Roessler, A., 2013. Observed subpolar gyre transports at the Mid-Atlantic Ridge (Thesis). Universität Bremen.

Roessler, A., Rhein, M., Kieke, D., Mertens, C., 2015. Long-term observations of North Atlantic Current transport at the gateway between western and eastern Atlantic: NAC transport observations at MAR. Journal of Geophysical Research Oceans 120, 4003-4027. doi:10.1002/2014JC010662.

Rossby, T., 1996. The North Atlantic Current and surrounding waters: At the crossroads. Reviews of Geophysics 34, (4), 463-481. doi:10.1029/96RG02214.

Rossby, T., Flagg, C.N., 2012. Direct measurement of volume flux in the Faroe-Shetland Channel and over the Iceland-Faroe Ridge. Geophysical Research Letters 39, L07602. doi:10.1029/2012GL051269 
Sandwell, D.T., Smith, W.H.F., Gille, S., Kappel, E., Jayne, S., Soofi, K., Coakley, B., Géli, L., 2006. Bathymetry from space: Rationale and requirements for a new, high-resolution altimetric mission. Terre Obs. Depuis Espac. Earth Space 338, 1049-1062.

doi:10.1016/j.crte.2006.05.014.

Sarafanov A., 2009. On the effect of the North Atlantic Oscillation on temperature and salinity of the subpolar North Atlantic intermediate and deep waters. ICES Journal of Marine Science 66 (7), 1448-1454. doi:10.1093/icesjms/fsp094.

Sarafanov, A., Falina, A., Mercier, H., Sokov, A., Lherminier, P., Gourcuff, C., Gladyshev, S., Gaillard, F., Daniault, N., 2012. Mean full-depth summer circulation and transports at the northern periphery of the Atlantic Ocean in the 2000s. Journal of Geophysical Research 117, C01014. doi:10.1029/2011JC007572.

Saunders, P.M., 1996. The Flux of Dense Cold Overflow Water Southeast of Iceland. J. Phys. Oceanogr. 26, 85-95. doi:10.1175/1520-0485(1996)026<0085:TFODCO > 2.0.CO;2

Saunders, P.M., 1994. The flux of overflow water through the Charlie-Gibbs Fracture Zone. Journal of Geophysical Research 99, 12343. doi:10.1029/94JC00527.

Schott, F., Stramma, L., Fischer, J., 1999. Interaction of the North Atlantic Current with the deep Charlie Gibbs Fracture Zone throughflow. Geophysical Research Letters 26, 369-372. doi:10.1029/1998GL900223.

Sutherland, D.A., Pickart, R.S., 2008. The East Greenland Coastal Current: Structure, variability, and forcing. Progress in Oceanography 78, 58-77.

doi:10.1016/j.pocean.2007.09.006.

Sy, A., Schauer, U., Meincke, J., 1992. The north-atlantic current and its associated hydrographic structure above and eastwards of the mid-atlantic ridge. Deep-Sea Research 39, 825-853. doi:10.1016/0198-0149(92)90124-C.

Talley, L.D., Pickard, G.L., Emery, W.J. (Eds.), 2011. Descriptive physical oceanography: an introduction, 6th ed. ed. Academic Press, Amsterdam ; Boston. ISBN: 978-0-7506-4552-2.

Thierry, V., de Boisséson, E., Mercier, H., 2008. Interannual variability of the Subpolar Mode Water properties over the Reykjanes Ridge during 1990-2006. Journal of Geophysical Research 113, C04016. doi:10.1029/2007JC004443.

Thurnherr, A.M., 2010. A Practical Assessment of the Errors Associated with Full-Depth LADCP Profiles Obtained Using Teledyne RDI Workhorse Acoustic Doppler Current Profilers. Journal of Atmospheric Oceanographic Technology 27, 1215-1227. doi:10.1175/2010JTECHO708.1.

Treguier, A.M., Theetten, S., Chassignet, E.P., Penduff, T., Smith, R., Talley, L., Beismann, J.O., Boning, C., 2005. The North Atlantic subpolar gyre in four high-resolution models. Journal of Physical Oceanography 35, 757-774. doi:10.1175/JPO2720.1. 
Våge, K., Pickart, R.S., Sarafanov, A., Knutsen, Ø., Mercier, H., Lherminier, P., van Aken, H.M., Meincke, J., Quadfasel, D., Bacon, S., 2011. The Irminger Gyre: Circulation, convection, and interannual variability. Deep Sea Res. I 58, 590-614.

doi:10.1016/j.dsr.2011.03.001.

Van Aken, H., De Boer, C., 1995. On the synoptic hydrography of intermediate and deepwater masses in the Iceland basin. Deep-Sea Research I 42, 165-189. doi:10.1016/09670637(94)00042-Q.

Van Aken, H.M., 2000. The hydrography of the mid-latitude northeast Atlantic Ocean I: The deep water masses. Deep-Sea Research I 47, 757-788. doi:10.1016/S0967-0637(99)00092-8.

Visbeck, M., 2002. Deep velocity profiling using lowered Acoustic Doppler Current Profilers: Bottom track and inverse solutions. Journal of Atmospheric and Oceanography Technology 19, 794-807. doi: 10.1175/1520-0426(2002)019<0794:DVPULA>2.0.CO;2.

Volkov, D.L., van Aken, H.M., 2005. Climate-related change of sea level in the extratropical North Atlantic and North Pacific in 1993-2003. Geophysical Research Letters 32, L14611. doi:10.1029/2005GL023097.

Worthington, L.V., 1976. On the North Atlantic circulation, The Johns Hopkins oceanographic studies. The Johns Hopkins university press, Baltimore; London. ISBN-13: 978-0801817427.

Xu, X., Schmitz, W.J., Hurlburt, H.E., Hogan, P.J., Chassignet, E.P., 2010. Transport of Nordic Seas overflow water into and within the Irminger Sea: An eddy-resolving simulation and observations. Journal of Geophysical Research 115, C12048. doi:10.1029/2010JC006351.

Yaremchuk, M.I., Nechaev, D.A., Thompson, K.R., 2001. Seasonal variation of the North Atlantic Current. J. Geophys. Res. Oceans 106, 6835-6851. doi:10.1029/2000JC900166 